\title{
Evaluating risk detection methods to uncover ontogenic- mediated adverse drug effect mechanisms in children
}

3 Authors:

4 Nicholas P. Giangreco ${ }^{1,2}$ and Nicholas P. Tatonetti ${ }^{1, *}$

$5 \quad{ }^{1}$ Departments of Systems Biology and Biomedical Informatics, Columbia University, 622 W.

$6168^{\text {th }}$ Street, New York, NY, 10032

7 2npg2108@cumc.columbia.edu, ORCID: 0000-0001-8138-4947

$8 \quad{ }^{*}$ Correspondence: npt2105@cumc.columbia.edu, ORCID: 0000-0002-2700-2597

\section{Abstract}

10 Background: Identifying adverse drugs effects (ADEs) in children is essential for preventing

11 disability and death from marketed drugs. At the same time, however, detection is challenging

12 due to dynamic biological processes during growth and maturation, called ontogeny, that alter

13 pharmacokinetics and pharmacodynamics. As a result, current data mining methodologies have

14 been limited to event surveillance and have not focused on investigating adverse event

15 mechanisms. There is an opportunity to design data mining methodologies to identify and

16 evaluate drug event patterns within observational databases for ontogenic-mediated adverse

17 event mechanisms. The first step of which is to establish statistical models that can identify

18 temporal trends of adverse effects across childhood. Results: Using simulation, we evaluated a

19 population stratification method (the proportional reporting ratio or PRR) and a population

20 modeling method (the generalized additive model or GAM) to identify and quantify ADE risk at

21 varying reporting rates and dynamics. We found that GAMs showed improved performance over

22 the PRR in detecting dynamic drug event reporting across child developmental stages. Moreover,

23 GAMs exhibited normally distributed and robust ADE risk estimation at all development stages

24 by sharing information across child development stages. Conclusions: Our study underscores the

25 opportunity for using population modeling techniques, which leverages drug event reporting

26 across development stages, to identify adverse drug effect risk resulting from ontogenic

27 mechanisms.

28 Keywords 
medRxiv preprint doi: https://doi.org/10.1101/2021.03.10.21253302; this version posted March 12, 2021. The copyright holder for this preprint (which was not certified by peer review) is the author/funder, who has granted medRxiv a license to display the preprint in perpetuity.

It is made available under a CC-BY 4.0 International license .

\section{Background}

31 Adverse drug events (ADEs) in children are common and can result in injury and death ${ }^{1,2}$.

32 Clinical trials rarely include children ${ }^{3}$ and pediatric-specific trials are limited in identifying

33 possible ADEs in the population ${ }^{4}$. Pediatric drug safety studies can evaluate large numbers of

34 ADEs from the population ${ }^{5}$ but current methodologies are limited in their ability to identify the

35 mechanisms that drive pediatric $\mathrm{ADEs}^{6}$. Children undergo evolutionarily conserved and

36 physiologically dynamic biological processes, collectively called ontogeny, as they grow and

37 develop from birth through adolescence ${ }^{7,8}$. The mechanisms may include varying protein

38 activity ${ }^{9,10}$ as well as include functional and structural changes that occur during maturation ${ }^{11,12}$.

39 These ontogenic changes can alter pharmacodynamics and pharmacokinetics resulting in adverse

40 effects, as is the case for doxorubicin-induced cardiotoxicity ${ }^{13}$ and valproate-induced

41 hepatotoxicity ${ }^{14}$. With a few notable exceptions, however, many pediatric adverse events are

42 idiopathic with no known, clear connection to developmental biology ${ }^{15,16}$. Additionally, adverse

43 event mechanisms established in adults may not translate to the pediatric population ${ }^{17}$. There is

44 an opportunity to combine known ontogenic biology with real-world pediatric drug effect data to

45 identify ontogenic-mediated adverse events.

46 To date, elucidation of ontogenic mechanisms has relied on hypothesis-driven approaches. For

47 example, juvenile mouse models have been used to identify genetic vulnerabilities of

48 hematopoiesis ${ }^{18}$ and investigate effects by a glutamatergic agonist on the neural developmental

49 sequence ${ }^{19}$ during early life. More recently, pharmacometric tools have been used to extrapolate

50 drug effects from adults to children, such as projecting acetaminophen exposure across pediatric

51 age groups ${ }^{20}$, and investigate drug action in children, such as predicting clearance of zidovudine 
medRxiv preprint doi: https://doi.org/10.1101/2021.03.10.21253302; this version posted March 12, 2021. The copyright holder for this preprint (which was not certified by peer review) is the author/funder, who has granted medRxiv a license to display the preprint in perpetuity.

It is made available under a CC-BY 4.0 International license .

52 during infancy ${ }^{21}$. However, juvenile animal studies are low-throughput and require complex

53 study designs ${ }^{22}$, and there is limited experimental data to parameterize manually designed

54 pharmacometric models ${ }^{23,24}$. While lacking specificity, top-down studies are complementary in

55 that they evaluate thousands of hypotheses simultaneously and can identify idiosyncratic effects

56 that would otherwise go unnoticed ${ }^{25,26}$. Moreover, analyses of large population datasets start

57 from clinically significant events which can take decades to identify ${ }^{27,28}$. Top-down studies can

58 close the pediatric evidence gap ${ }^{23}$ by sifting through large databases to identify clinically

59 significant although perhaps less studied and rare adverse drug events during the period of child

60 growth and development.

61 While pediatric pharmacovigilance has been able to identify adverse drug events, it is limited in

62 identifying growth and development processes that underlie those observations ${ }^{10,29}$. A common

63 approach when identifying ADEs is to stratify the pediatric population into age groups which

64 directly reduces the amount of data available to identify ADEs during childhood. The

65 Proportional Reporting Ratio, which was designed to be sensitive even when data is scarce ${ }^{30}$, is

66 an established detection method and has been shown to unmask ADE signal within child

67 development stages compared to detection within the larger pediatric population ${ }^{31}$. However,

68 reduced data within these strata was shown to significantly affect PRR detection performance

69 across pediatric age groups ${ }^{31}$. To investigate pediatric ADEs, the continuous, time-dependent

70 biological processes during growth and development suggest using all information across child

71 development stages.

72 Generalized additive models (GAMs) are supervised machine learning approaches that can

73 quantify non-linear effects reflective of natural phenomena ${ }^{32}$. GAMs may be able to quantify

74 signal reflecting dynamic, continuous processes such as ontogeny. These models are extensively 
medRxiv preprint doi: https://doi.org/10.1101/2021.03.10.21253302; this version posted March 12, 2021. The copyright holder for this preprint (which was not certified by peer review) is the author/funder, who has granted medRxiv a license to display the preprint in perpetuity.

It is made available under a CC-BY 4.0 International license .

75 used for spatial and temporal analysis in ecological studies ${ }^{33}$, such as explaining cardiovascular

76 mortality risk from heat waves over time ${ }^{34}$ and rat infestation from environmental factors within

77 geographic areas ${ }^{35}$. Similar to evaluating ecological responses using shared information across

78 time or space, we can evaluate adverse events from temporally-connected ontogenic processes

79 using shared information across child development stages.

80 We performed the first study to directly evaluate dynamic drug event reporting during childhood.

81 We performed a data simulation and augmentation study that 1) simulated drug event reporting

82 temporal trends of different effect sizes and shapes, 2) augmented existing pediatric drug event

83 data by inserting the simulated reporting rates within observational data, and 3) evaluated

84 population stratification (PRR) and modeling (GAM) methods to detect these injected ADE

85 reporting dynamics. We found the detection scores generated by the GAM showed improved risk

86 estimates and increased detection of drug event reporting among the various simulated dynamics

87 compared to the PRR. Detection methods that capture temporal adverse drug event dynamics

88 within observational databases can improve our understanding of the interactions between child

89 developmental biology and adverse drug effects.

\section{Results}

\section{Pediatric FAERS}

92 There were 339,741 pediatric drug event reports in FAERS, which contained 519,555 unique

93 drug-event pairs. We randomly sampled 500 drug-event pairs to be augmented with simulated

94 drug event reporting dynamics, representing our positive control set. We then randomly sampled

95 another 10,000 complementary drug-event pairs where the underlying data was untouched, 
medRxiv preprint doi: https://doi.org/10.1101/2021.03.10.21253302; this version posted March 12, 2021. The copyright holder for this preprint (which was not certified by peer review) is the author/funder, who has granted medRxiv a license to display the preprint in perpetuity.

It is made available under a CC-BY 4.0 International license .

96 representing our negative control set. We showed there was no significant difference in the

97 amount of drug-event reporting between FAERS and the negative control (2-sample Student t-

98 test $\mathrm{p}$-value $=0.92)$ or positive control $(\mathrm{p}$-value $=0.87)$ drug-event pairs (Figure 1$)$.

\section{Data simulation and augmentation}

100 We augmented the 500 drug-event pairs in the positive control set with simulated drug event

101 reporting across child development stages (see Methods). Augmenting the positive control data

102 with drug event reporting dynamics did not have a systematic effect on the amount of drug event

103 reporting compared to the untouched negative control set (Figure S1). However, applying the

104 PRR and GAM detection methods onto the positive control data showed the ADE risk scores

105 reflected the simulated dynamics classes (Figure 2).

106

107 The GAM generated ADE risk that resembled normally distributed scores (Shapiro-Wilk test

108 average p-value and 95\% confidence interval: 0.45 [0.059, 0.88], 90mse: 0.20 [4.67E-04, 0.92])

109 in comparison to the PRR (score: 0.11 [1.80E-09, 0.56], 90mse: 0.077 [2.48E-09, 0.93]) at child

110 development stages (Figure 3A). Moreover, 47\% of PRR scores were zero and 18\% were unable

111 to be computed, on average for drug-event pairs (Figure 3B).

\section{ADE dynamics detection performance}

113 We compared the performance of the GAM and PRR for detecting drug event reporting

114 dynamics (see Methods). Additionally, we further investigated the performance contribution by

115 each child development stage within the dynamics class. We found that the GAM had improved

116 detection of drug event reporting dynamics compared to the PRR both overall (Figure 4A) and

117 within each child development stage (Figure 4B). Moreover, the GAM had similar overall 
medRxiv preprint doi: https://doi.org/10.1101/2021.03.10.21253302; this version posted March 12, 2021. The copyright holder for this preprint (which was not certified by peer review) is the author/funder, who has granted medRxiv a license to display the preprint in perpetuity.

It is made available under a CC-BY 4.0 International license .

118 performance (Figure 5) as well as sensitivity (Figure S3) at low drug event reporting compared

119 to the sensitive-by-design PRR.

120 ADE dynamics sensitivity analysis

121 We investigated the detection of drug event reporting dynamics with increasingly rare adverse

122 events within child development stages (Figure S4 and see Methods). The ADE risk scores

123 generated by the GAM showed dependent, flexible risk estimates across child development

124 stages unlike the PRR (Figure S5). We found that the GAM had significantly higher performance

125 (Figure 6) and sensitivity (Figure S5) to detect the various drug event reporting dynamics as

126 adverse events became rare at child development stages.

127 Real-world validation

128 We compared the performance of the GAM and PRR for detecting drug-event pairs in a real-

129 world pediatric reference set of 26 drug-event pairs (see Methods and Figure S6). We found that

130 the GAM had slightly improved overall performance and sensitivity compared to the PRR for

131 detecting pediatric adverse drug events (Table 1 and Figure S7). Moreover, we found no

132 difference in the fraction of drug-event pairs with significant ADE risk at child development

133 stages (Table 2; proportion test $\mathrm{p}$-value $=0.39$ ). We found that the GAM identified two real-world

134 pediatric drug events with putative dynamic ADE risk (Figure 7). Specifically, the GAM showed

135 periods of lower risk during early and late childhood and higher risk during the middle stages of

136 childhood. While the PRR and GAM performed approximately the same overall, the GAM

137 captured dynamic ADE risk where the PRR did not. 
medRxiv preprint doi: https://doi.org/10.1101/2021.03.10.21253302; this version posted March 12, 2021. The copyright holder for this preprint (which was not certified by peer review) is the author/funder, who has granted medRxiv a license to display the preprint in perpetuity.

It is made available under a CC-BY 4.0 International license.

\section{Discussion}

139 Children undergo a period of dynamic growth and development, presenting a challenge in

140 identifying and evaluating adverse drug events ${ }^{10,36}$. We hypothesize that dynamic ontogenic

141 processes as children grow and develop may be reflected by temporal drug event reporting in the

142 population. We presented the first study to evaluate drug event reporting patterns across

143 childhood in large observational data. We found that GAMs, a population modeling technique,

144 outperformed the PRR, a population stratification method, as well as generated robust risk scores

145 to detect adverse drug events during childhood. This work represents a first step in transitioning

146 from performing event surveillance towards uncovering putative mechanisms of pediatric

147 adverse drug events.

148 The goal of our study is to improve the specificity of top-down data mining for generating

149 pediatric drug safety hypotheses. Our study hypothesis was temporal drug event reporting trends

150 found in observational data are dependent on ontogeny, which exhibits high and low molecular

151 and physiological levels throughout childhood ${ }^{7,37,38}$. To test this within a top-down approach, we

152 generated temporal trends in observational data to correspond with temporal trends from

153 ontogeny as opposed to identifying temporal trends from frequency ${ }^{39}$ or feature-derived ${ }^{40,41}$

154 measures directly from observed data. This motivated both simulating dynamic drug event

155 reporting rates and then augmenting real-world data to generate different classes of dynamic

156 drug event reporting trends. While we simulated dynamic drug event reporting rates, we showed

157 that augmenting the FAERS data did not change the overall characteristics of the pediatric drug

158 reports. This was crucial for establishing the use of real-world drug event data to evaluate hidden

159 dynamic reporting trends. Importantly the ADE detection methods were in fact able to identify 
medRxiv preprint doi: https://doi.org/10.1101/2021.03.10.21253302; this version posted March 12, 2021. The copyright holder for this preprint (which was not certified by peer review) is the author/funder, who has granted medRxiv a license to display the preprint in perpetuity.

It is made available under a CC-BY 4.0 International license .

160 the simulated dynamics within the data. The data simulation and augmentation of FAERS laid

161 the foundation for evaluating statistical methods to investigate ontogenic-mediated adverse event

162 mechanisms.

163 We found that the generalized additive model (GAM) showed improved detection of dynamic

164 drug event reporting compared to the proportional reporting ratio (PRR). While the PRR

165 produces ADE risk scores that were more erratic and unable to be computed, the GAM scores

166 were both more flexible and robust. The GAM assumes a flexible relationship yet reduces

167 'wiggliness' to stable risk estimates based on observed data ${ }^{42,43}$. While bayesian modeling

168 techniques such as Monte Carlo Markov Chain can also learn flexible relationships from

169 observed data, these models still require expert knowledge to build, implement, and interpret ${ }^{44}$.

170 The GAM, on the other hand, generates an interpretable smooth relationship in a familiar

171 regression framework ${ }^{32}$ that shares information across child development stages. Using this

172 shared information framework, the GAM was able to detect injected dynamic ADE risks across

173 childhood even when drug event reporting was low. We further showed that the GAM not only

174 generated visually dynamic ADE risk when injecting dynamics, but we also identified putative

175 dynamic risk for real-world psychiatric adverse events from exposure to montelukast medication

176 (Figure S8). We demonstrated that GAMs can be used to detect dynamic reporting of adverse

177 drug events by sharing information across child development stages.

178 This study has some limitations. First, observational data has inherent bias and confounding

179 factors which may affect both the sample of drug-event pairs in our study as well as the

180 performance of the detection methods. We showed that the random sample of drug events

181 correspond to the reporting patterns found in the FAERS database. Also, performing a power

182 analysis allowed for identifying drug events for which the detection methods were able to 
medRxiv preprint doi: https://doi.org/10.1101/2021.03.10.21253302; this version posted March 12, 2021. The copyright holder for this preprint (which was not certified by peer review) is the author/funder, who has granted medRxiv a license to display the preprint in perpetuity.

It is made available under a CC-BY 4.0 International license.

183 identify the dynamic reporting to provide a fair performance comparison. Second, other

184 regulatory agencies, such as the Food and Drug Administration and European Medicines

185 Agency, define pediatric age ranges for development stages by different methods. While varying

186 child stage definitions were not explored here, we chose stages defined by NICHD that were

187 established after consultation and agreement among several US-based organizations such as the

188 American Academy of Pediatrics and the Centers for Disease Control and Prevention ${ }^{45}$. Third,

189 fixed development stages may serve more useful in drug regulations and trial design than

190 representing dynamic child growth and development. Nevertheless, the detection performance

191 and risk scores for both methods could only be compared when considering data found within

192 child development strata. Fortunately, the further advantage of the GAM is its ability to model

193 childhood as a continuous period using age without restrictive strata. This increases the sharing

194 of information for identifying adverse event risk during childhood which may cross development

195 stages and affect specific periods during childhood.

\section{Conclusion}

197 In this study, we evaluated ADE risk detection methods to identify dynamic drug event reporting

198 within observational data. By simulating drug event reporting and augmenting simulated rates

199 into existing observational data, we can make comparisons between methods to detect dynamic

200 drug event reporting patterns. We found GAMs result in more robust scores, overall improved

201 performance to detect dynamics, and improved ability to detect simulated and real-world

202 pediatric drug-events compared to the state-of-the-art PRR method. This study lays the

203 foundation to detect and evaluate pediatric adverse drug events for ontogenic-mediated

204 mechanisms. 
medRxiv preprint doi: https://doi.org/10.1101/2021.03.10.21253302; this version posted March 12, 2021. The copyright holder for this preprint (which was not certified by peer review) is the author/funder, who has granted medRxiv a license to display the preprint in perpetuity.

It is made available under a CC-BY 4.0 International license.

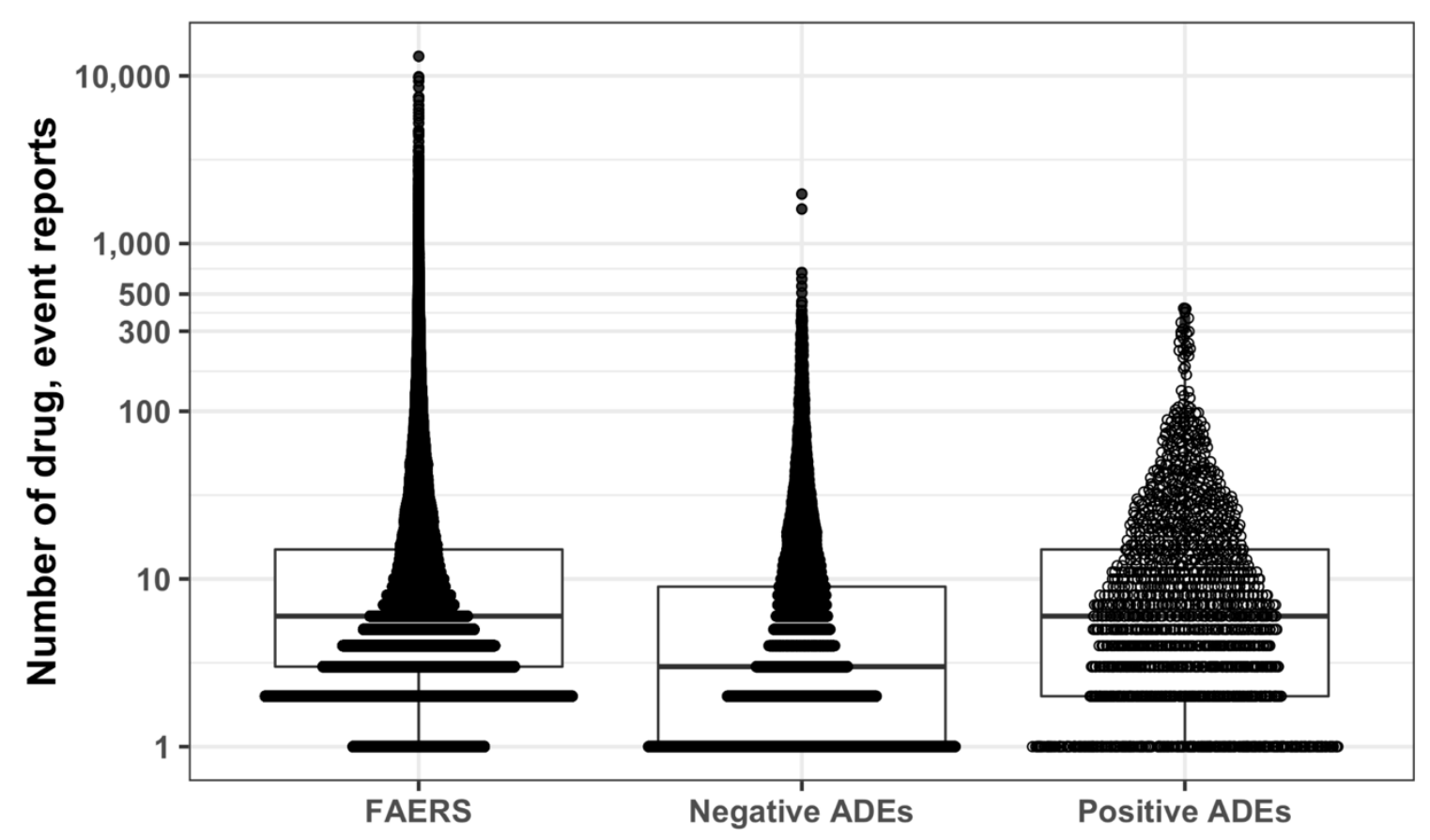

Fig. 1 Comparison of drug event reporting in drug-event datasets. A boxplot summary overlayed by the amount of drug event reports for drug-event pairs between (pediatric) FAERS $(\mathrm{N}=519,555)$, the positive control set $(\mathrm{N}=500)$, and the negative control set $(\mathrm{N}=10000)$. ' $\mathrm{N}$ ' is the sample size. 
medRxiv preprint doi: https://doi.org/10.1101/2021.03.10.21253302; this version posted March 12, 2021. The copyright holder for this preprint (which was not certified by peer review) is the author/funder, who has granted medRxiv a license to display the preprint in perpetuity.

A)

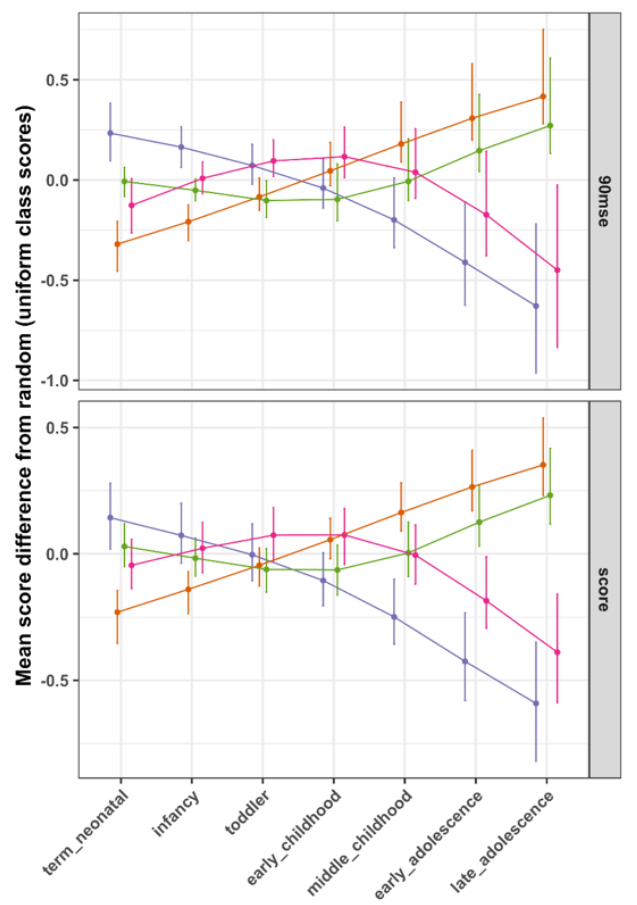

B)
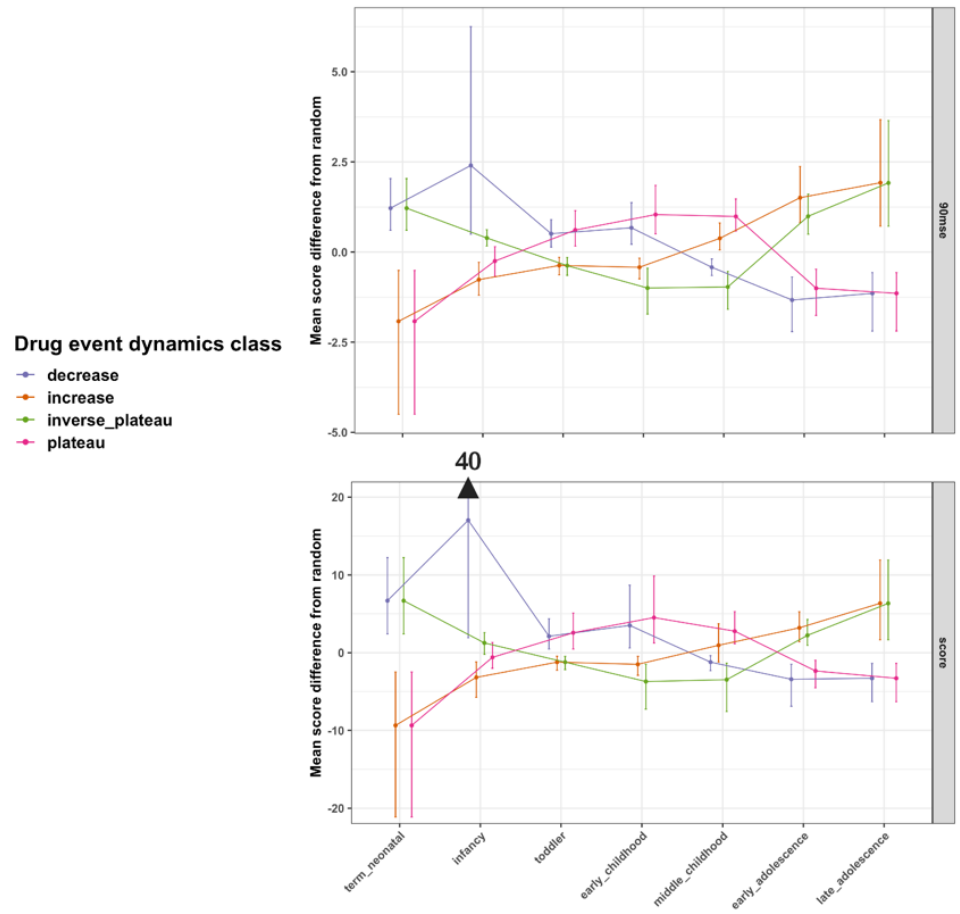

Fig. 2 ADE detection method risk score distribution across child development stages. Risk scores resulting from applying the A) GAM and B) PRR ADE detection methods on the positive control drug-event pair data for each dynamics class. The score distributions at each child development stage were produced after 100 bootstraps of the original scores for each method and score type. We show the average difference of the resampled score distributions between a given drug event reporting dynamics class and uniform (random drug event reporting across childhood) with the $95 \%$ confidence interval. 
medRxiv preprint doi: https://doi.org/10.1101/2021.03.10.21253302; this version posted March 12, 2021. The copyright holder for this preprint (which was not certified by peer review) is the author/funder, who has granted medRxiv a license to display the preprint in perpetuity.

It is made available under a CC-BY 4.0 International license .

A)

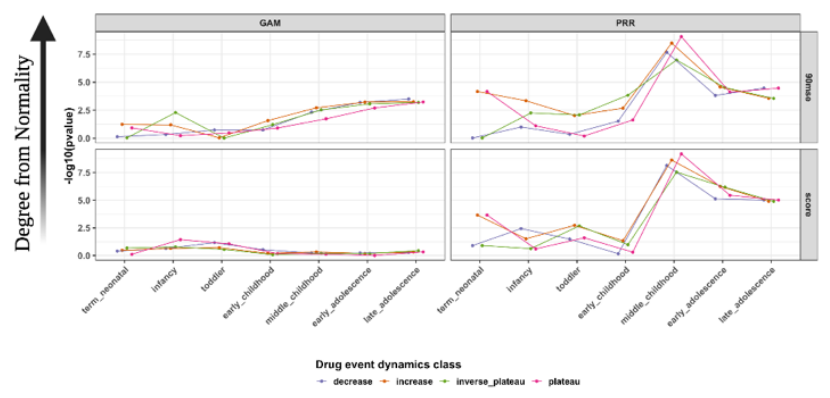

B)

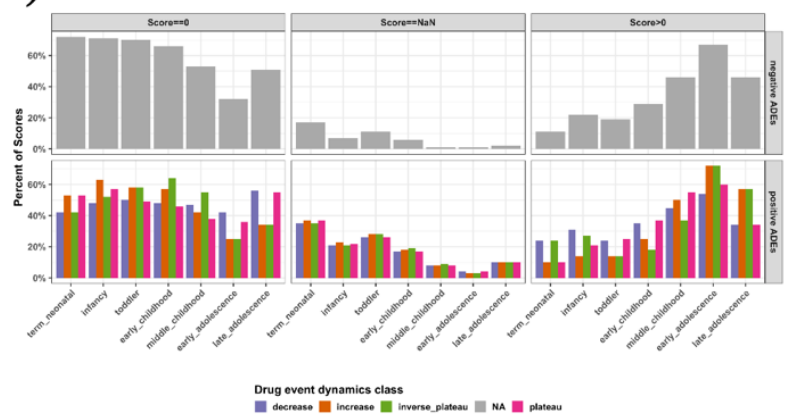

Fig. 3 Summary of ADE detection method risk score quality.

A) Deviation from a normal score distribution for each method and score type across child development stages. The score distributions were produced after 100 bootstraps of the original scores at each child development stage. The Shapiro-Wilk test calculated a significance probability value for the resampled scores being drawn from a normal distribution. B) PRR detection method risk score quality summary. Across the positive and negative controls as well as drug event reporting dynamics classes, we calculated the number of scores with a zero, NaN (unable to be computed; the drug not reported at a stage or the drug not reported with the event at a stage), or nonzero positive score across child development stages. 
medRxiv preprint doi: https://doi.org/10.1101/2021.03.10.21253302; this version posted March 12, 2021. The copyright holder for this preprint (which was not certified by peer review) is the author/funder, who has granted medRxiv a license to display the preprint in perpetuity.

A)

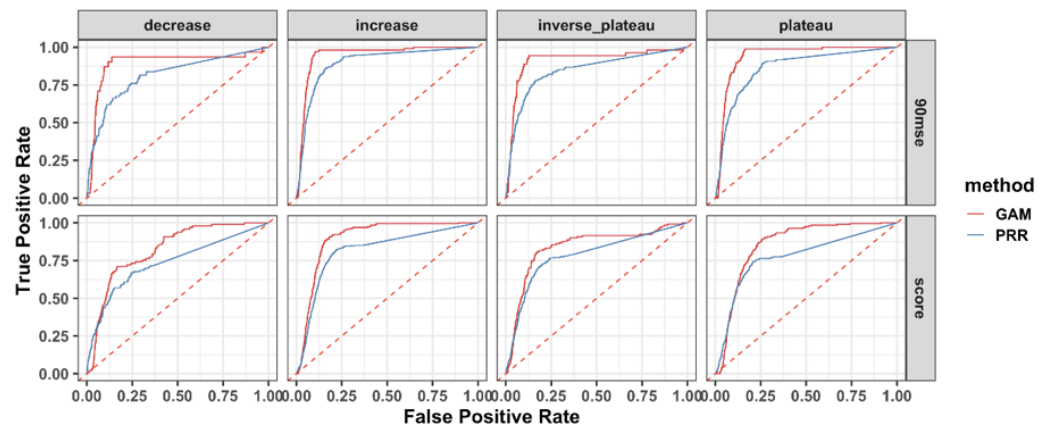

B)

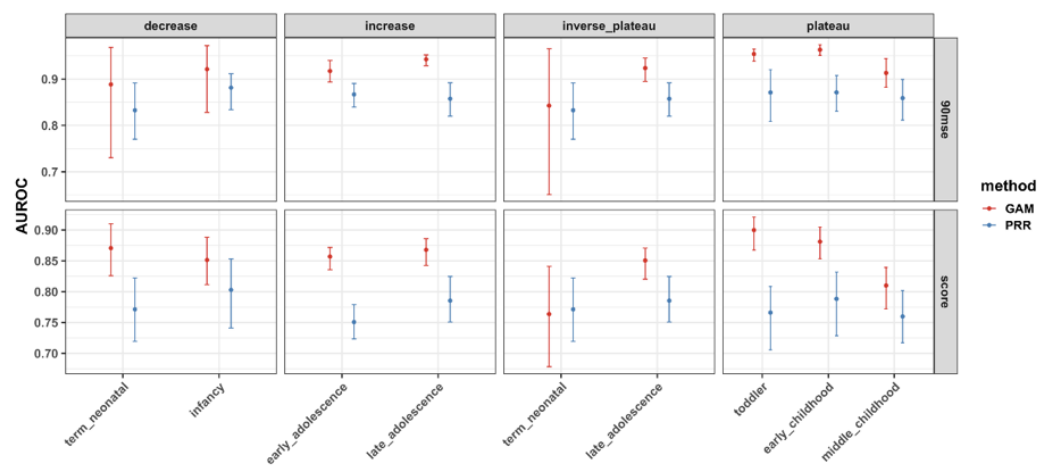

Fig. 4 GAM and PRR drug event dynamic detection performance. A) The receiver operating characteristic curves showing the true positive rate versus the false positive rate for each method and score type by drug event reporting dynamics class. B) The area under the receiver operating characteristic curve (AUROC) for each child development stage within each dynamics class. 
medRxiv preprint doi: https://doi.org/10.1101/2021.03.10.21253302; this version posted March 12, 2021. The copyright holder for this preprint (which was not certified by peer review) is the author/funder, who has granted medRxiv a license to display the preprint in perpetuity. It is made available under a CC-BY 4.0 International license.

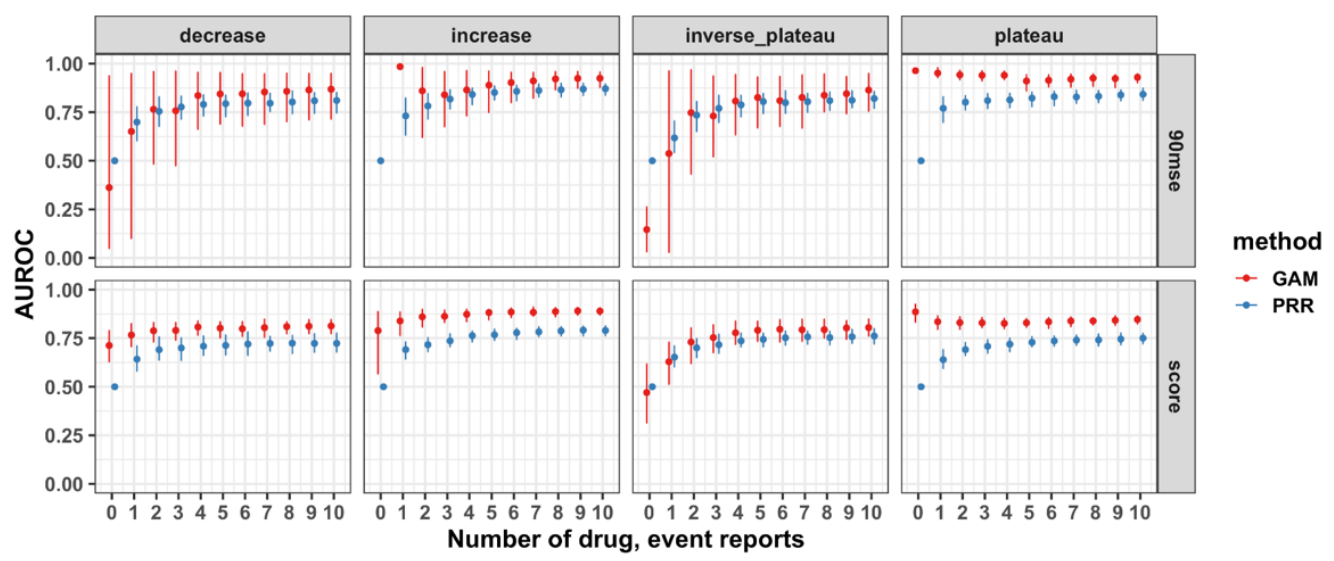

Fig. 5 GAM and PRR detection performance at low drug event reporting. The AUROC was computed for each method and score type to detect dynamics only utilizing (drug-event, stage, dynamic) triples with up to a given amount of drug event reports. 
medRxiv preprint doi: https://doi.org/10.1101/2021.03.10.21253302; this version posted March 12, 2021. The copyright holder for this preprint (which was not certified by peer review) is the author/funder, who has granted medRxiv a license to display the preprint in perpetuity.

Table 1 Real-world pediatric drug-event detection performance. The area under the receiver operating characteristic curve (AUROC) and sensitivity or true positive rate to detect real-world pediatric drug-events observed within FAERS per each method and score type. The prediction threshold for the sensitivity was the null statistic for each method (null threshold: $\mathrm{GAM}==0 ; \mathrm{PRR}==1$ ). The performance interval is the $95 \%$ confidence interval.

\begin{tabular}{|c|c|c|c|c|c|c|c|c|}
\hline \multirow{2}{*}{} & \multicolumn{9}{|c|}{ Real-world pediatric drug-event detection performance } \\
\cline { 2 - 9 } & \multicolumn{9}{|c|}{ AUROC } & \multicolumn{3}{c|}{ Sensitivity } \\
\cline { 2 - 9 } & \multicolumn{3}{|c|}{$90 \mathrm{mse}$} & \multicolumn{2}{|c|}{ score } & 90mse & \multicolumn{3}{c|}{ score } \\
\hline & PRR & GAM & PRR & GAM & PRR & GAM & PRR & GAM \\
\hline Performance value & 0.62 & 0.65 & 0.62 & 0.73 & 0.28 & 0.28 & 0.49 & 0.85 \\
& {$[0.58,0.66]$} & {$[0.59,0.69]$} & {$[0.58,0.67]$} & {$[0.69,0.77]$} & {$[0.22,0.36]$} & {$[0.23,0.35]$} & {$[0.40,0.56]$} & {$[0.81,0.89]$} \\
\hline
\end{tabular}

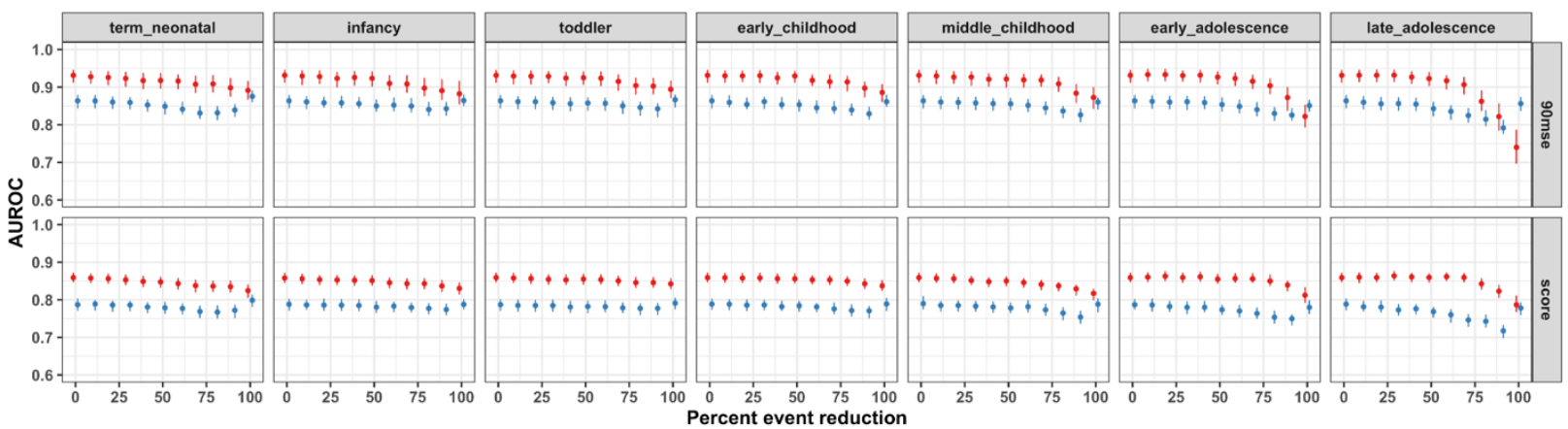

Fig. 6 GAM and PRR performance to detect dynamic patterns of rare adverse events. The AUROC for detecting various classes of drug event reporting dynamics as event reporting was reduced at child development stages. The event reporting for drug-event pairs was reduced at $10 \%$ decrements only within a specific child development stage. For example, $0 \%$ event reporting reduction indicates no reduction in event reporting and $100 \%$ event reporting reduction indicates all event reports were removed. 
medRxiv preprint doi: https://doi.org/10.1101/2021.03.10.21253302; this version posted March 12, 2021. The copyright holder for this preprint (which was not certified by peer review) is the author/funder, who has granted medRxiv a license to display the preprint in perpetuity.

It is made available under a CC-BY 4.0 International license.

Table 2 ADE detection method risk score quality and significance on real-world pediatric drug-events. The number of drug-event pairs that contained a child development stage with a risk score of each score quality (null threshold: GAM==0; PRR==1). A 90\% lower bound score above the null threshold indicates a significant risk.

\begin{tabular}{|r|c|c|c|c|c|c|}
\hline $\begin{array}{c}\text { Number of drug- } \\
\text { event pairs with } \\
\text { score quality in } \\
\text { atleast one stage }\end{array}$ & Zero & NaN & Finite & Infinite & $\begin{array}{c}\text { Score } \\
\text { above null }\end{array}$ & $\begin{array}{c}90 \% \text { lower bound } \\
\text { above null }\end{array}$ \\
\hline GAM & 0 & 0 & 26 & 0 & 26 & 14 \\
\hline PRR & 23 & 14 & 25 & 5 & 26 & 18 \\
\hline
\end{tabular}




\section{A)}

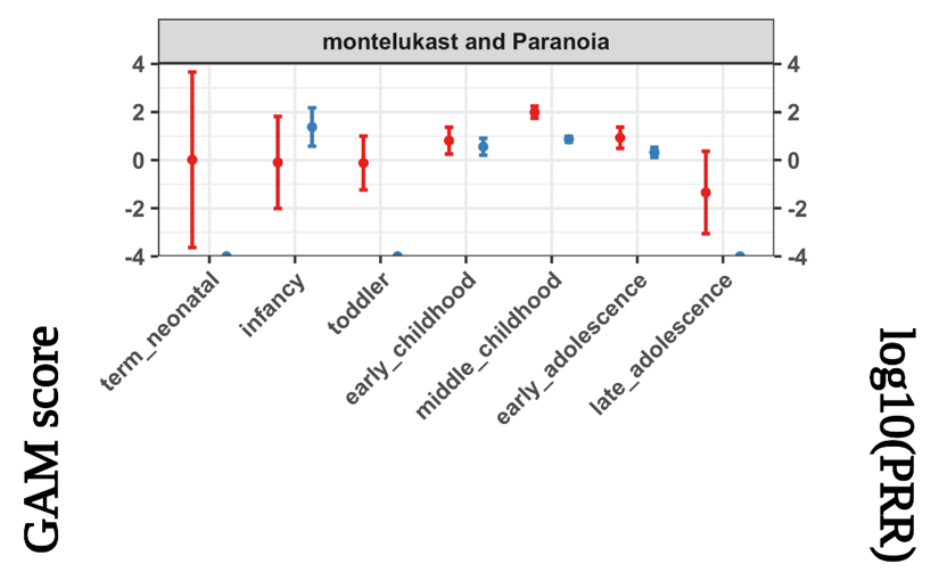

B)

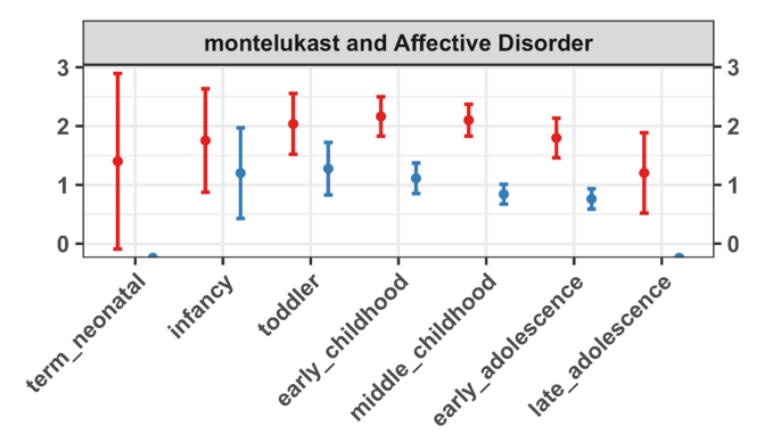

Fig. 7 GAM and PRR detection scores on putative real-world dynamic adverse drug events. We highlight two psychiatric adverse events, A) Paranoia and B) Affective Disorder, from exposure to the drug montelukast exhibiting dynamic ADE risks across child development stages.

\section{Methods}

215 ADE data source

216 We retrieved drug event reports from the Food and Drug Administration's openFDA ${ }^{46}$ download

217 page, utilizing an API key with extended permissions, containing the FAERS data. Using custom 
medRxiv preprint doi: https://doi.org/10.1101/2021.03.10.21253302; this version posted March 12, 2021. The copyright holder for this preprint (which was not certified by peer review) is the author/funder, who has granted medRxiv a license to display the preprint in perpetuity.

It is made available under a CC-BY 4.0 International license.

218 python notebooks and scripts available in the 'openFDA_drug_event-parsing' github repository

219 (DOI: 10.5281/zenodo.4464544), we extracted and formatted all drug event reports prior to the

220 third quarter of 2019. Data fields included the safety report identifier, age value, age code

221 e.g. year, adverse event MedDRA concept code (preferred terms), and drug RxNorm code

222 (various) used in our analyses. The age value was standardized to year units for categorizing

223 reports into the 7 child development stages according to the Eunice Kennedy Shriver National

224 Institute of Child and Human Development ${ }^{45}$. Adverse drug event MedDRA codes were mapped

225 to standard concept identifiers using concept tables ${ }^{48}$ from the OMOP common data model. The

226 drug RxNorm code was similarly translated to the standard RxNorm concept identifier

227 (ingredient level) in OMOP and was further mapped to the equivalent ATC concept identifier

228 (ATC $5^{\text {th }}$ level) using the concept relationship table. The occurrence of an adverse drug event is

229 defined as any safety report where both the adverse event and drug concepts are reported

230 together. The pediatric report space for any adverse drug event is all reports which have age

231 above zero and less than or equal to 21 years old which is the upper bound for the late

232 adolescence child development stage. The drug event data for a given drug-event pair composed

233 of 339,741 safety reports with a binary indicator for reports of the event and drug, as well as the

234 category of NICHD child development stage for the report's patient.

\section{Simulated ADE dynamics}

236 The objective of this study was to evaluate detection of drug-event reporting as the reporting rate

237 changes across child development stages with varying dynamics and effect sizes. We assert that

238 reporting dynamics during childhood reflect ontogenic profiles observed on molecular,

239 functional, and structural levels $7,37,38$. 
medRxiv preprint doi: https://doi.org/10.1101/2021.03.10.21253302; this version posted March 12, 2021. The copyright holder for this preprint (which was not certified by peer review) is the author/funder, who has granted medRxiv a license to display the preprint in perpetuity.

It is made available under a CC-BY 4.0 International license .

240 We simulated dynamic ADE reporting by combining hyperbolic tangent functions that produced

241 symmetric probability distributions around a given effect size to define the probability of event

242 reporting at drug reports. These dynamic reporting classes represent nonlinear trends of drug-

243 event reports across childhood. The average drug and event reporting across reports equaled the

244 event reporting rate multiplied by a fold change factor resulting in the effect size of dynamic

245 drug event reporting. The fold change followed a negative exponential distribution with rate

246 parameter 0.75 resulting in a fold change distribution ranging from 1 to 10 (Figure S9). The

247 simulated reporting probabilities were distributed to safety reports in age ascending order

248 reflecting a desired dynamic distribution of ADE reporting across childhood. We designed 5

249 different dynamic reporting rates, namely 'uniform' (random), 'increase', 'decrease', 'plateau',

250 and 'inverse_plateau' (Figure S10).

251 ADE data augmentation

252 We augmented the original drug event data from FAERS with the simulated drug event reporting

253 dynamics. We randomly selected 500 drug-event pairs to be the positive control set. We

254 augmented the drug event data for each pair with dynamics previously described that we want to

255 detect. We then randomly selected 10,000 mutually exclusive drug-event pairs to be the negative

256 control set which were not augmented and represented reporting of drugs with events within

257 FAERS. Differences of the average drug event reporting between the drug-event sets was

258 computed by comparing 10 million resamples of each distribution.

260 Augmenting the positive control drug-event pairs resulted in 5 sets of 500 drug-event pairs,

261 forming (drug-event, stage, dynamic) triples. The (drug-event, stage, uniform dynamic) triple 
medRxiv preprint doi: https://doi.org/10.1101/2021.03.10.21253302; this version posted March 12, 2021. The copyright holder for this preprint (which was not certified by peer review) is the author/funder, who has granted medRxiv a license to display the preprint in perpetuity.

It is made available under a CC-BY 4.0 International license .

262 scores were the reference distribution for comparing the average difference in scores, after 20

263 resamples, with ADE risk scores from the other dynamics classes.

\section{ADE detection methods}

265 We applied two ADE detection methods to the positive and negative control drug-event sets. We

266 chose a population stratification (PRR) and modeling (GAM) method to evaluate detection of

267 ADE dynamics when stratifying the data or by sharing information across child development

268 stages, respectively.

269 We employed the Proportional Reporting Ratio (PRR):

$$
\frac{\frac{a}{a+c}}{\frac{b}{b+d}}
$$

271 where ' $a$ ' is the number of reports with the drug and event, ' $b$ ' is the number of reports without

272 the drug and with the event, ' $c$ ' is the number of reports with the drug and without the event, and

273 ' $d$ ' is the number of reports without the drug or event of interest. The resulting score is the event

274 reporting prevalence with the drug compared to without the drug. We generated PRR scores for

275 each child development stage resulting in 7 scores for each drug-event pair. The PRR scores

276 were $\log 10$ transformed when conducting the Shapiro-Wilk test for normality.

277 We also evaluated the logistic generalized additive model ${ }^{49}$ (GAMs):

$$
g(E(\text { Event }))=s(\text { nichd }) * \text { Drug }
$$

279 where $g$ is a logit link function, E(Event) is the expected value of event reporting, $s$ is a spline 280 function with a penalized cubic basis, nichd is the child development stage of the report's 
medRxiv preprint doi: https://doi.org/10.1101/2021.03.10.21253302; this version posted March 12, 2021. The copyright holder for this preprint (which was not certified by peer review) is the author/funder, who has granted medRxiv a license to display the preprint in perpetuity.

It is made available under a CC-BY 4.0 International license.

281 subject, and Drug is an indicator i.e. 0 or 1 of drug reporting. Details for GAMs can be found at 282 references ${ }^{42,50}$ and we specified the model using the $m g c v$ package in $\mathrm{R}$.

283 Briefly, the GAM is a flexible statistical model that captures nonlinear effects of covariates onto

284 a response. In this paper, we model the effect of the child development stage interacting with

285 drug reporting on the reporting of an event where the event is the reporting of the MedDRA

286 preferred term and the drug is the reporting of the ATC $5^{\text {th }}$ level drug concept. The $s()$ function

287 is a spline function where the interaction of the child development stage (main effect) and the

288 drug (interaction using the 'by' variable) is modeled according to a set of basis functions. Each

289 development stage defines the knot (7 in total) in which the expectation of event reporting is

290 quantified. In the spline function, a penalized cubic spline basis (bs='cs') is used for fitting the

291 basis functions where the first and second derivative of the event expectation is zero at each

292 knot, resulting in a smooth event expectation across stages. To mitigate overfitting or

293 'wiggliness', we used a penalized iterative restricted likelihood approach, called 'fREML', with

294 a wiggliness penalty in the objective function. Fitting the GAM model (using the 'bam' function

295 and discrete $=\mathrm{T}$ ) produces coefficient terms, similar to beta coefficients in logistic regression, for

296 each child development stage for the association of the adverse event being reported in

297 interaction with reporting the drug. We generated GAM scores for each child development stage

298 resulting in 7 scores for each drug-event pair. It is important to note that all GAM scores

299 produced were finite, nonzero values.

300 The scores generated by each method have different variations and uncertainty in the estimated

301 population value. We additionally determined the lower confidence bound in which the

302 population-based score would be greater than $90 \%$ of score replicates. The population score and 
medRxiv preprint doi: https://doi.org/10.1101/2021.03.10.21253302; this version posted March 12, 2021. The copyright holder for this preprint (which was not certified by peer review) is the author/funder, who has granted medRxiv a license to display the preprint in perpetuity.

It is made available under a CC-BY 4.0 International license .

303 the $90 \%$ lower confidence bound, called 'score' and '90mse' respectively, are the score types for

304 each method.

306 We performed a power analysis to determine which of the positive control drug-event pairs could

307 be detected for each method and score type. The generated scores may not show a drug and event

308 association (score above the null statistic or a significance association) for a child development

309 stage due to the method's different assumptions and biases when applied onto observational data.

310 To mitigate these issues, we determined the drug event data characteristics, namely the number

311 of drug reports and the effect size, for each method in which reporting dynamics could be

312 detected at or above $t=80 \%$ power or true positive rate. Specifically, for the (drug-event, stage,

313 dynamic) triple scores in the positive control set, we determined the power to differentiate scores

314 at high reporting rates about a given score threshold (GAM score threshold==0; PRR score

315 threshold==1). The reporting rates were higher at different child development stages for each

316 dynamics class e.g. the 'increase' dynamics class had higher reporting at the 'early_adolescence'

317 and 'late_adolescence' stages (Table S1). The scores from (drug-event, stage, dynamic) triples

318 with a high reporting rate were only considered for reflecting dynamic drug event reporting

319 associations. The scores from (drug-event, stage, dynamic) triples with a low reporting rate were

320 not considered further due to spurious scores generated at stages without injected signal. The

321 drug event characteristics were determined for both the estimated population score ('score') and

322 the $90 \%$ lower bound score ('90mse') that represent scores with lower and higher confidence,

323 respectively, for the 'true' population score. 
medRxiv preprint doi: https://doi.org/10.1101/2021.03.10.21253302; this version posted March 12, 2021. The copyright holder for this preprint (which was not certified by peer review) is the author/funder, who has granted medRxiv a license to display the preprint in perpetuity.

It is made available under a CC-BY 4.0 International license .

324 Choosing drug-event pairs at or exceeding the characteristics for each method and score type at

325 or above $t=80 \%$ power resulted in a superset of (drug-event, stage, dynamic) triples designated

326 as positives in a reference standard for each drug event reporting dynamics class (Table S2). The

327 negative control set contained the same (drug-event, stage) doubles or 70,000 scores for each

328 reference standard. Excluding the drug-event scores generated by the uniform class, there were 4

329 reference standards of positive and negative drug-event pairs for each ADE reporting dynamics

330 class used for detection performance evaluation.

331 ADE dynamic detection performance

332 We evaluated the GAM and PRR methods to detect drug event reporting dynamics across the

333 child development stages. Specifically, we determined the performance in differentiating scores

334 from (drug-event, stage, dynamic) triples in the positive control set versus the negative control

335 (drug-event, stage) score doubles. The positive control set contained a superset of the 500 (drug-

336 event, stage, dynamic) score triples (Table S2). The negative control set contained the same

337 (drug-event, stage) doubles or 70,000 scores for each reference standard. For each of the four

338 reference standards, we quantified performance metrics including the sensitivity, specificity, and

339 area under the receiver operating characteristic (AUROC) curve using the R package ROCR for

340 each detection method and score type. Confidence intervals for the AUROC were calculated

341 through bootstrapping (100 resamples) the score distributions and calculating performance

342 metric values.

343 Dynamics sensitivity analysis

344 We assessed the sensitivity of the ADE detection methods to detect drug event reporting

345 dynamics within child development stages. We artificially reduced, at $10 \%$ decrements, the event 
medRxiv preprint doi: https://doi.org/10.1101/2021.03.10.21253302; this version posted March 12, 2021. The copyright holder for this preprint (which was not certified by peer review) is the author/funder, who has granted medRxiv a license to display the preprint in perpetuity.

It is made available under a CC-BY 4.0 International license .

346 reporting rate at each child development stage separately. Specifically, at each reduced stage, we

347 determined the sensitivity of each method and score type to detect (drug-event, stage, dynamic)

348 score triples compared to the same negative control (drug-event, stage) score doubles at that

349 same reduced stage. Sensitivity was assessed iteratively at the $10 \%$ decrements within each child

350 development stage. We calculated the AUROC and power metrics to quantify sensitivity to drug

351 event reporting dynamics for each method and score type.

\section{Real-world ADE validation}

353 We applied the ADE detection methods on observed FAERS data for drug-event pairs within the

354 pediatric drug-event reference standard from the Global Research in Pediatrics consortium ${ }^{51}$. A

355 machine-readable dataset can be found at the 'GRiP_pediatric_ADE-reference_set' github

356 repository (DOI: 10.5281/zenodo.4453379). We assigned drug-event pairs with epidemiological

357 or mechanistic evidence in children (Control==' $\left.C^{\prime}\right)$ as the positive class $(\mathrm{N}=26)$, and the cross-

358 product of all drugs and events that were complementary to drug-event pairs in the reference set

359 as the negative class $(\mathrm{N}=123)$. We calculated the AUROC using the ROCR package in $\mathrm{R}$ and the

360 true positive rate using the null statistic of each method as the prediction threshold.

\section{List of Abbreviations}

362 ADE: adverse drug event; FAERS: Food and Drug Administration Adverse Event Reporting

363 System; GAM: generalized additive model; PRR: proportional reporting ratio; NICHD: national

364 institute of child and human development; AUROC: area under the receiver operating

365 characteristic curve; TPR: true positive rate; ATC: anatomical therapeutic class; DOI: digital

366 object identifier. 
medRxiv preprint doi: https://doi.org/10.1101/2021.03.10.21253302; this version posted March 12, 2021. The copyright holder for this preprint (which was not certified by peer review) is the author/funder, who has granted medRxiv a license to display the preprint in perpetuity.

It is made available under a CC-BY 4.0 International license .

\section{Availability of Data and Materials}

368 The datasets and code supporting the conclusions of this article are available in the

369 'evaluating_ontogenic_ade_risk' Github repository, DOI: 10.5281/zenodo.4585585.

370

\section{Declarations}

372 None.

\section{References}

374 1. Impicciatore P, Choonara I, Clarkson A, Provasi D, Pandolfini C, Bonati M. Incidence of

375 adverse drug reactions in paediatric in/out-patients: a systematic review and meta-analysis

376 of prospective studies. Br J Clin Pharmacol. 2001;52(1):77-83. doi:10.1046/j.0306-

$377 \quad$ 5251.2001.01407.x

378 2. Smyth RMD, Gargon E, Kirkham J, et al. Adverse drug reactions in children--a systematic review. PLoS One. 2012;7(3):e24061. doi:10.1371/journal.pone.0024061

380 3. Giangreco NP, Elias JE, Tatonetti NP. No population left behind: Improving paediatric 381 drug safety using informatics and systems biology. Br J Clin Pharmacol. Published online

382 December 17, 2020:bcp.14705. doi:10.1111/bcp.14705

383 4. Benjamin DK, Smith PB, Sun MJM, et al. Safety and Transparency of Pediatric Drug

384 Trials. Arch Pediatr Adolesc Med. 2009;163(12):1080-1086.

385 doi:10.1001/archpediatrics.2009.229 
medRxiv preprint doi: https://doi.org/10.1101/2021.03.10.21253302; this version posted March 12, 2021. The copyright holder for this preprint (which was not certified by peer review) is the author/funder, who has granted medRxiv a license to display the preprint in perpetuity.

It is made available under a CC-BY 4.0 International license .

386 5. de Bie S, Ferrajolo C, Straus SMJM, et al. Pediatric Drug Safety Surveillance in FDAAERS: A Description of Adverse Events from GRiP Project. Garattini S, ed. PLoS One. 2015;10(6):e0130399. doi:10.1371/journal.pone.0130399

6. Castro-Pastrana LI, Carleton BC. Improving pediatric drug safety: need for more efficient clinical translation of pharmacovigilance knowledge. J Popul Ther Clin Pharmacol $=$ J la Ther des Popul la Pharmacol Clin. 2011;18(2):e76-88. http://journals.sagepub.com/doi/10.1038/jcbfm.2012.176

7. Crespi B. The evolutionary biology of child health. Proc R Soc B Biol Sci. 2011;278(1711):1441-1449. doi:10.1098/rspb.2010.2627

8. Yaffe S, Estabrook RW, Pitluck S, Davis JR. Rational Therapeutics for Infants and Children.; 2000. doi:10.17226/9816

9. Johnson T. The development of drug metabolising enzymes and their influence on the susceptibility to adverse drug reactions in children. Toxicology. 2003;192(1):37-48. doi:10.1016/S0300-483X(03)00249-X

10. Becker ML, Leeder JS. Identifying genomic and developmental causes of adverse drug 401 reactions in children. Pharmacogenomics. 2010;11(11):1591-1602. doi:10.2217/pgs.10.146

403 11. de Graaf-Peters VB, Hadders-Algra M. Ontogeny of the human central nervous system:

404 What is happening when? Early Hum Dev. 2006;82(4):257-266.

405 doi:10.1016/j.earlhumdev.2005.10.013

406 12. Simon AK, Hollander GA, McMichael A. Evolution of the immune system in humans 
medRxiv preprint doi: https://doi.org/10.1101/2021.03.10.21253302; this version posted March 12, 2021. The copyright holder for this preprint (which was not certified by peer review) is the author/funder, who has granted medRxiv a license to display the preprint in perpetuity.

It is made available under a CC-BY 4.0 International license .

from infancy to old age. Proceedings Biol Sci. 2015;282(1821):20143085.

408 doi:10.1098/rspb.2014.3085

409 13. Carvalho FS, Burgeiro A, Garcia R, Moreno AJ, Carvalho RA, Oliveira PJ. DoxorubicinInduced Cardiotoxicity: From Bioenergetic Failure and Cell Death to Cardiomyopathy. Med Res Rev. 2014;34(1):106-135. doi:10.1002/med.21280

412 14. Guo H-L, Jing X, Sun J-Y, et al. Valproic Acid and the Liver Injury in Patients with 413 Epilepsy: An Update. Curr Pharm Des. 2019;25(3):343-351. doi:10.2174/1381612825666190329145428

415 15. Moon YE. Paradoxical reaction to midazolam in children. Korean J Anesthesiol. 2013;65(1):2-3. doi:10.4097/kjae.2013.65.1.2

417 16. Kawakami Y, Fujii S, Ishikawa G, Sekiguchi A, Nakai A, Takase M. Valproate-induced 418 polycystic ovary syndrome in a girl with epilepsy: A case study. J Nippon Med Sch. 2018;85(5):287-290. doi:10.1272/jnms.JNMS.2018_85-46

420 17. Cui N, Wu F, Lu W, et al. Doxorubicin-induced cardiotoxicity is maturation dependent 421 due to the shift from topoisomerase II $\alpha$ to II $\beta$ in human stem cell derived cardiomyocytes. N. 2019;23(7):4627-4639. doi:10.1111/jcmm.14346

423 18. Park SO, Wamsley HL, Bae K, et al. Conditional Deletion of Jak2 Reveals an Essential Role in Hematopoiesis throughout Mouse Ontogeny: Implications for Jak2 Inhibition in 425 Humans. PLoS One. 2013;8(3):1-14. doi:10.1371/journal.pone.0059675

426 19. Marret S, Mukendi R, Gadisseux JF, Gressens P, Evrard P. Effect of ibotenate on brain 
medRxiv preprint doi: https://doi.org/10.1101/2021.03.10.21253302; this version posted March 12, 2021. The copyright holder for this preprint (which was not certified by peer review) is the author/funder, who has granted medRxiv a license to display the preprint in perpetuity.

It is made available under a CC-BY 4.0 International license .

Neuropathol Exp Neurol. 1995;54(3):358-370. doi:10.1097/00005072-199505000-00009

429 20. Jiang X-L, Zhao P, Barrett J, Lesko L, Schmidt S. Application of Physiologically Based

430 Pharmacokinetic Modeling to Predict Acetaminophen Metabolism and Pharmacokinetics

431 in Children. CPT Pharmacometrics Syst Pharmacol. 2013;2(10):80.

432 doi: $10.1038 /$ psp.2013.55

433 21. Krekels EHJ, Neely M, Panoilia E, et al. From pediatric covariate model to

434 semiphysiological function for maturation: Part I-extrapolation of a covariate model from

435 morphine to zidovudine. CPT Pharmacometrics Syst Pharmacol. 2012;1(1):1-8.

$436 \quad$ doi: $10.1038 /$ psp.2012.11

437 22. Baldrick P. Juvenile animal testing in drug development - Is it useful? Regul Toxicol

438 Pharmacol. 2010;57(2-3):291-299. doi:10.1016/j.yrtph.2010.03.009

439 23. Goulooze SC, Zwep LB, Vogt JE, et al. Beyond the Randomized Clinical Trial:

440 Innovative Data Science to Close the Pediatric Evidence Gap. Clin Pharmacol Ther.

2020;107(4):786-795. doi:10.1002/cpt.1744

442 24. Brussee JM, Calvier EAM, Krekels EHJ, et al. Children in clinical trials: towards

443 evidence-based pediatric pharmacotherapy using pharmacokinetic-pharmacodynamic

444 modeling. Expert Rev Clin Pharmacol. 2016;9(9):1235-1244.

445 doi:10.1080/17512433.2016.1198256

446 25. Christensen ML, Davis RL. Identifying the "Blip on the Radar Screen": Leveraging Big

447 Data in Defining Drug Safety and Efficacy in Pediatric Practice. J Clin Pharmacol.

448 2018;58(January):S86-S93. doi:10.1002/jcph.1141 
medRxiv preprint doi: https://doi.org/10.1101/2021.03.10.21253302; this version posted March 12, 2021. The copyright holder for this preprint (which was not certified by peer review) is the author/funder, who has granted medRxiv a license to display the preprint in perpetuity. It is made available under a CC-BY 4.0 International license .

449 26. Tatonetti NP. Translational medicine in the Age of Big Data. Brief Bioinform.

450 2019;20(2):457-462. doi:10.1093/bib/bbx116

451 27. Berlin JA, Glasser SC, Ellenberg SS. Adverse event detection in drug development:

452 Recommendations and obligations beyond phase 3. Am J Public Health. 2008;98(8):1366-

453 1371. doi:10.2105/AJPH.2007.124537

454 28. Etwel FA, Rieder MJ, Bend JR, Koren G. A Surveillance Method for the Early

455 Identification of Idiosyncratic Adverse Drug Reactions. Drug Saf. 2008;31(2):169-180.

456 doi:10.2165/00002018-200831020-00006

457 29. Star K, Sandberg L, Bergvall T, Choonara I, Caduff-Janosa P, Edwards IR. Paediatric

458 safety signals identified in VigiBase: Methods and results from Uppsala Monitoring

459 Centre. Pharmacoepidemiol Drug Saf. 2019;28(5):680-689. doi:10.1002/pds.4734

460 30. Evans SJW, Waller PC, Davis S. Use of proportional reporting ratios (PRRs) for signal 461 generation from spontaneous adverse drug reaction reports. Pharmacoepidemiol Drug Saf.

2001;10(6):483-486. doi:10.1002/pds.677

463 31. Osokogu OU, Dodd C, Pacurariu A, Kaguelidou F, Weibel D, Sturkenboom MCJM. Drug

464 Safety Monitoring in Children: Performance of Signal Detection Algorithms and Impact

465 of Age Stratification. Drug Saf. 2016;39(9):873-881. doi:10.1007/s40264-016-0433-x

466 32. Hastie T, Tibshirani R, Friedman J. Elements of Statistical Learning. 2nd editio. Springer;

2008. http://web.stanford.edu/ hastie/pub.htm

468 33. Guisan A, Edwards TC, Hastie T. Generalized linear and generalized additive models in 469 studies of species distributions: setting the scene. Ecol Modell. 2002;157(2-3):89-100. 
medRxiv preprint doi: https://doi.org/10.1101/2021.03.10.21253302; this version posted March 12, 2021. The copyright holder for this preprint (which was not certified by peer review) is the author/funder, who has granted medRxiv a license to display the preprint in perpetuity.

doi:10.1016/S0304-3800(02)00204-1

471 34. Yin Q, Wang J. The association between consecutive days' heat wave and cardiovascular

472 disease mortality in Beijing, China. BMC Public Health. 2017;17(1):1-10.

473 doi: $10.1186 /$ s12889-017-4129-7

474 35. Tamayo-Uria I, Mateu J, Escobar F, Mughini-Gras L. Risk factors and spatial distribution 475 of urban rat infestations. J Pest Sci (2004). 2014;87(1):107-115. doi:10.1007/s10340-013$476 \quad 0530-\mathrm{x}$

477 36. Fabiano V, Mameli C, Zuccotti GV. Adverse drug reactions in newborns, infants and $478 \quad$ toddlers: pediatric pharmacovigilance between present and future. Expert Opin Drug Saf. 2012;11(1):95-105. doi:10.1517/14740338.2011.584531

37. Saghir SA, Khan SA, McCoy AT. Ontogeny of mammalian metabolizing enzymes in humans and animals used in toxicological studies. Crit Rev Toxicol. 2012;42(5):323-357. doi:10.3109/10408444.2012.674100

38. Gunewardena SS, Yoo B, Peng L, et al. Deciphering the Developmental Dynamics of the Mouse Liver Transcriptome. Buratti E, ed. PLoS One. 2015;10(10):e0141220. doi:10.1371/journal.pone.0141220

39. Bohn J, Kortepeter C, Muñoz M, Simms K, Montenegro S, Dal Pan G. Patterns in spontaneous adverse event reporting among branded and generic antiepileptic drugs. Clin Pharmacol Ther. 2015;97(5):508-517. doi:10.1002/cpt.81 
medRxiv preprint doi: https://doi.org/10.1101/2021.03.10.21253302; this version posted March 12, 2021. The copyright holder for this preprint (which was not certified by peer review) is the author/funder, who has granted medRxiv a license to display the preprint in perpetuity.

It is made available under a CC-BY 4.0 International license .

medical records. BMC Med Inform Decis Mak. 2019;19(1):1-21. doi:10.1186/s12911-018-

492 $0717-4$

493 41. Zhao J, Papapetrou P, Asker L, Boström H. Learning from heterogeneous temporal data in electronic health records. J Biomed Inform. 2017;65:105-119.

495 doi:10.1016/j.jbi.2016.11.006

42. Wood SN. Generalized Additive Models: An Introduction with R, Second Edition.; 2017. doi:10.1201/9781315370279

43. Helwig NE. Regression with ordered predictors via ordinal smoothing splines. Front Appl Math Stat. 2017;3(July):1-13. doi:10.3389/fams.2017.00015

500 44. Simpson D, Rue H, Riebler A, Martins TG, Sørbye SH. Penalising model component 501 complexity: A principled, practical approach to constructing priors. Stat Sci. 2017;32(1):128. doi:10.1214/16-STS576

503 45. Williams K, Thomson D, Seto I, et al. Standard 6: Age groups for pediatric trials. Pediatrics. 2012;129(SUPPL. 3):S153-S160. doi:10.1542/peds.2012-0055I

46. Kass-Hout TA, Xu Z, Mohebbi M, et al. OpenFDA: An innovative platform providing access to a wealth of FDA's publicly available data. J Am Med Informatics Assoc. 2016;23(3):596-600. doi:10.1093/jamia/ocv153

508 47. Giangreco NP. ngiangre/openFDA_drug_event_parsing: Repository for python notebooks and scripts for parsing the json-formatted drug event reports collected by the FDA.

$510 \quad$ Published online 2021. doi:https://zenodo.org/badge/latestdoi/246321623

511 48. OHDSI. Athena. Accessed January 17, 2021. https://athena.ohdsi.org/search-terms/start 
medRxiv preprint doi: https://doi.org/10.1101/2021.03.10.21253302; this version posted March 12, 2021. The copyright holder for this preprint (which was not certified by peer review) is the author/funder, who has granted medRxiv a license to display the preprint in perpetuity. It is made available under a CC-BY 4.0 International license .

512 49. Buja BYA, Hastie T, Tibshirani R. Linear Smoothers and Additive Models.

$513 \quad 2016 ; 17(2): 453-510$.

514 https://scholar.google.com/scholar_lookup?journal=The+Annals + of + Statistics\&title=Line

515 ar + smoothers + and + additive + models\&author $=\mathrm{A}+$ Buja\&author $=\mathrm{T}+$ Hastie\&author $=\mathrm{R}+\mathrm{Tibs}$

516 hirani\&publication_year=1989\&pages=453-510\&

517 50. Hastie T, Tibshirani R. Generalized additive models for medical research. Stat Methods

518 Med Res. 1995;4(3):187-196. doi:10.1177/096228029500400302

519 51. Osokogu OU, Fregonese F, Ferrajolo C, et al. Pediatric drug safety signal detection: a new

520 drug-event reference set for performance testing of data-mining methods and systems.

521 Drug Saf. 2015;38(2):207-217. doi:10.1007/s40264-015-0265-0

522 52. Giangreco N. GRiP_pediatric_ADE-reference_set. Published 2020. Accessed October 21, 523 2020. https://github.com/ngiangre/GRiP_pediatric_ADE-reference_set

524 53. Giangreco NP. ngiangre/evaluating_ontogenic_ade_risk. Published online 2021.

525 doi: $10.5281 /$ zenodo.4585585 
medRxiv preprint doi: https://doi.org/10.1101/2021.03.10.21253302; this version posted March 12, 2021. The copyright holder for this preprint (which was not certified by peer review) is the author/funder, who has granted medRxiv a license to display the preprint in perpetuity.

It is made available under a CC-BY 4.0 International license.
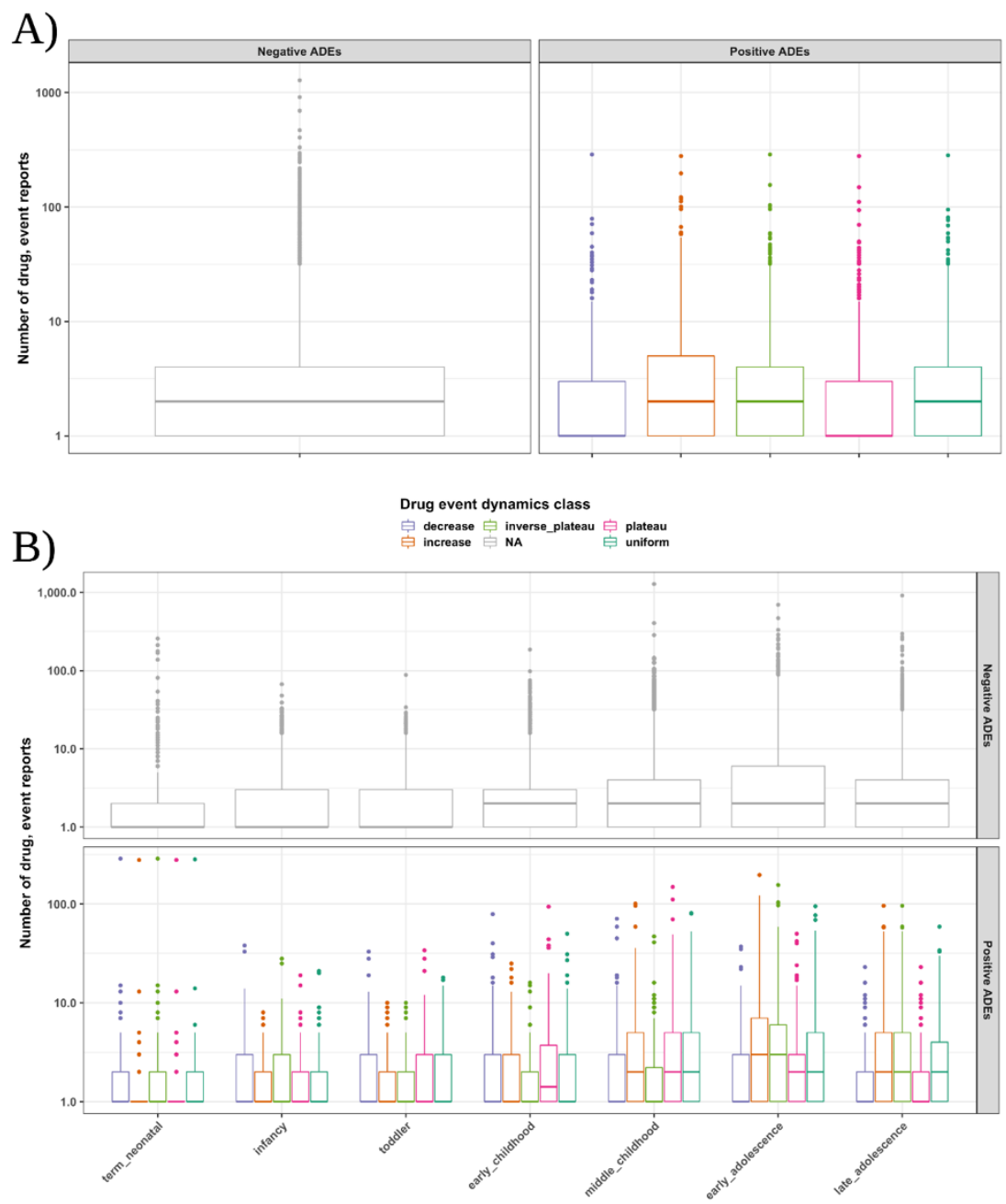

Fig. S1 Drug event reporting for positive and negative controls. The distribution of drug-event reporting between positive and negative control set drug-event pairs across A) dynamics classes and B) child development stages. 
medRxiv preprint doi: https://doi.org/10.1101/2021.03.10.21253302; this version posted March 12, 2021. The copyright holder for this preprint (which was not certified by peer review) is the author/funder, who has granted medRxiv a license to display the preprint in perpetuity.

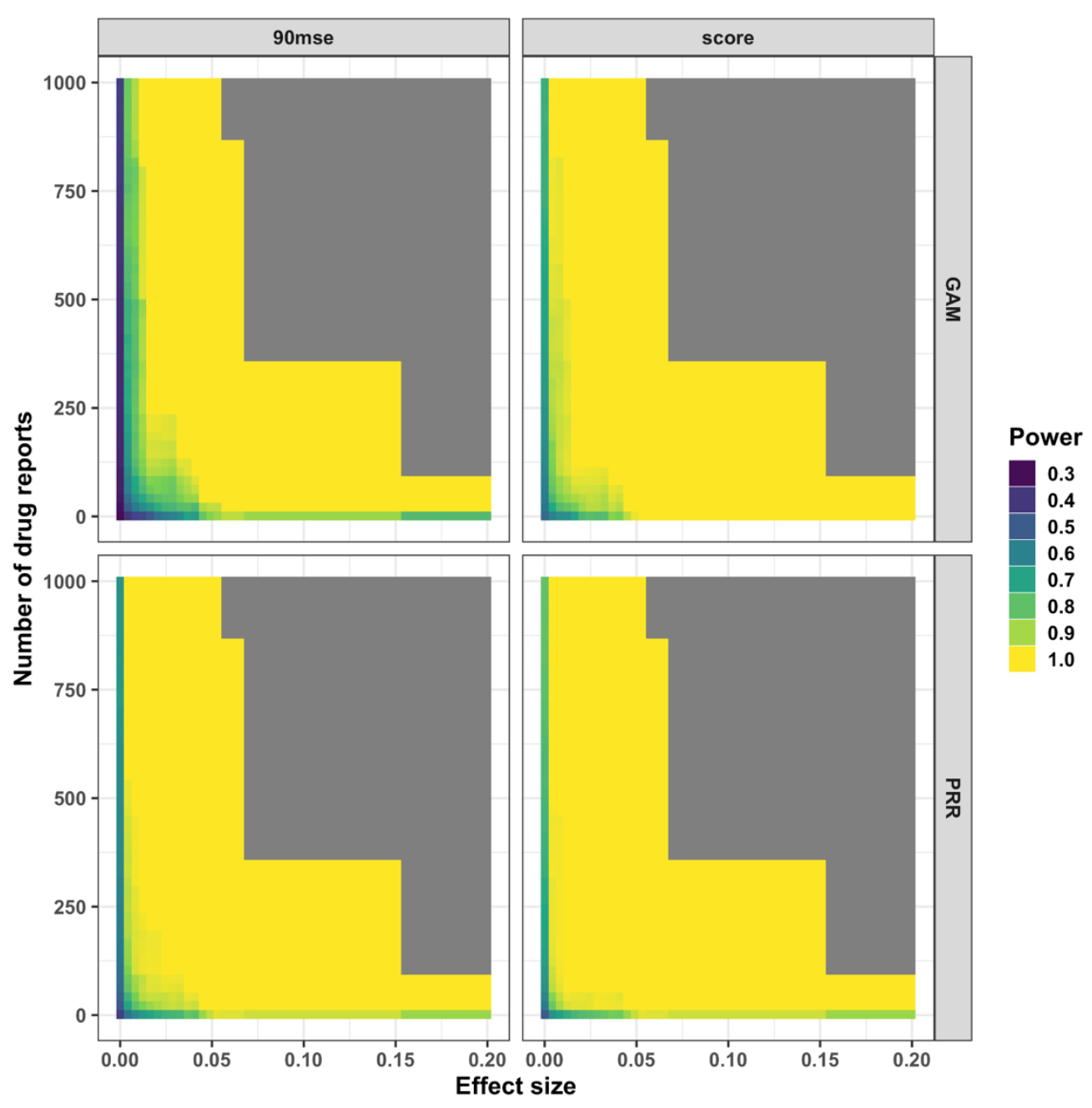

Fig. S2 Power graph detecting drug-event pairs with dynamics for each method and score type. The number of drug reports and effect size determined the scores evaluated to detect an association between the drug and event co-occurrence. The scores used were from child development stages with a high reporting rate determined by the dynamic class. 
medRxiv preprint doi: https://doi.org/10.1101/2021.03.10.21253302; this version posted March 12, 2021. The copyright holder for this preprint (which was not certified by peer review) is the author/funder, who has granted medRxiv a license to display the preprint in perpetuity. It is made available under a CC-BY 4.0 International license.

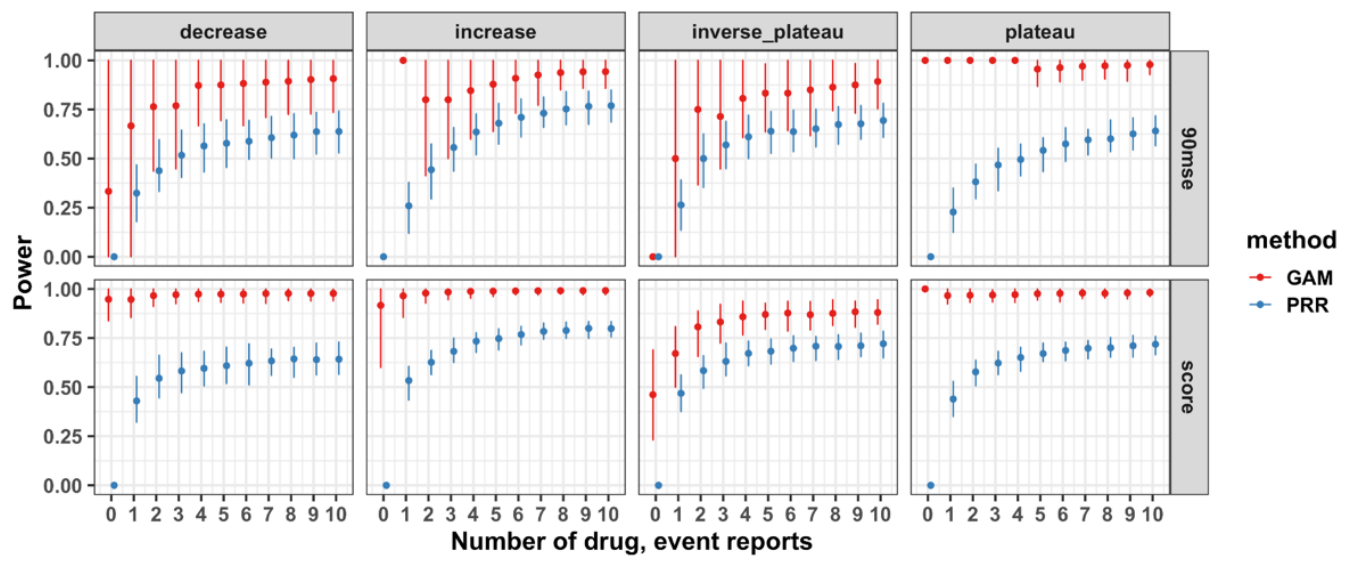

Fig. S3 GAM and PRR detection sensitivity at low drug event reporting. The sensitivity or true positive rate was computed for each method and score type to detect dynamics only utilizing (drug-event, stage, dynamic) triples with a given amount of drug event reports. 
medRxiv preprint doi: https://doi.org/10.1101/2021.03.10.21253302; this version posted March 12, 2021. The copyright holder for this preprint (which was not certified by peer review) is the author/funder, who has granted medRxiv a license to display the preprint in perpetuity.

It is made available under a CC-BY 4.0 International license .

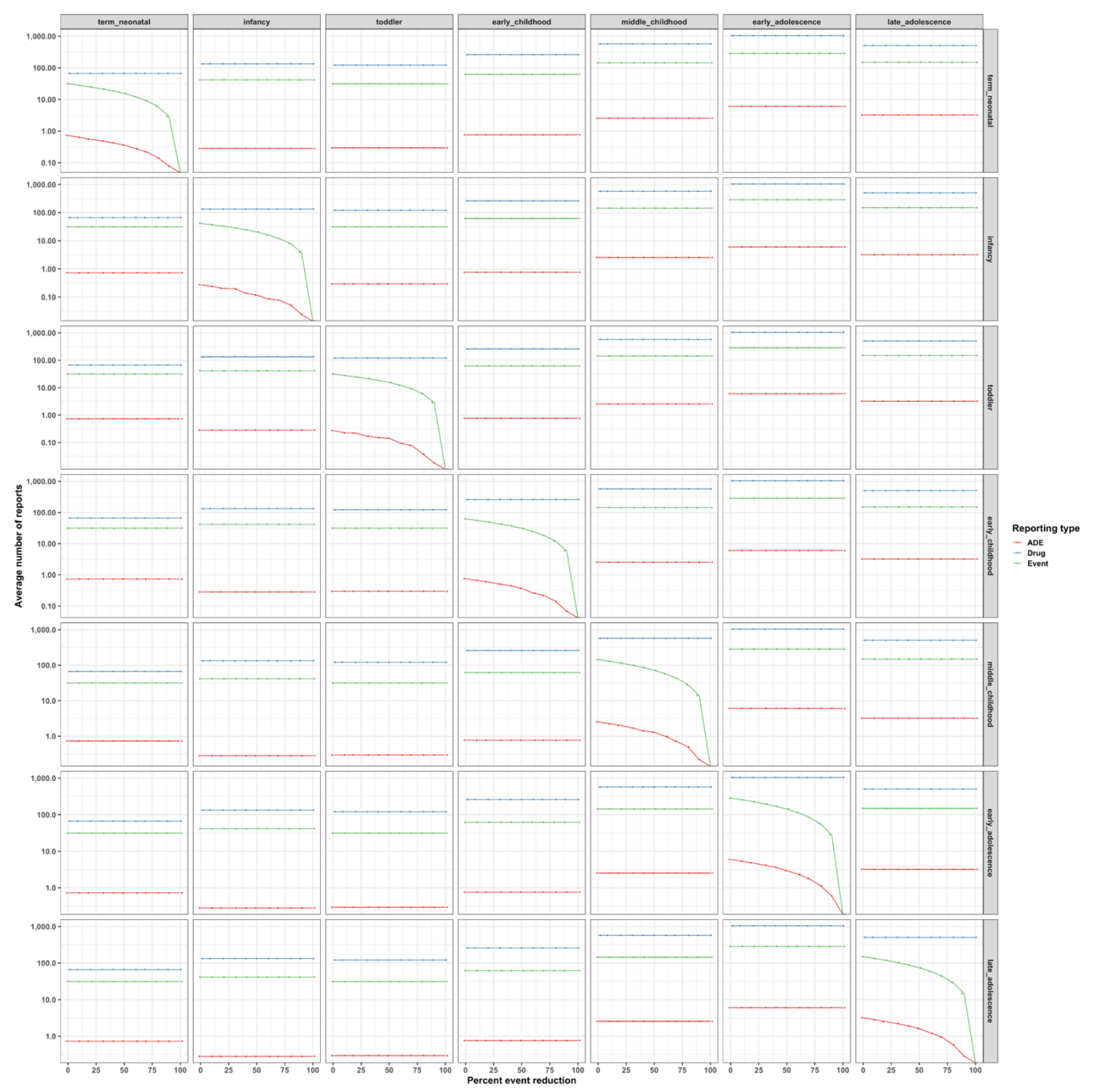

Fig. S4 Drug and event reporting as adverse events become rare at child development stages. The average number of drug, event, and drug event reports are shown at each child development stage as event reporting is reduced by $10 \%$ at each child development stage. 


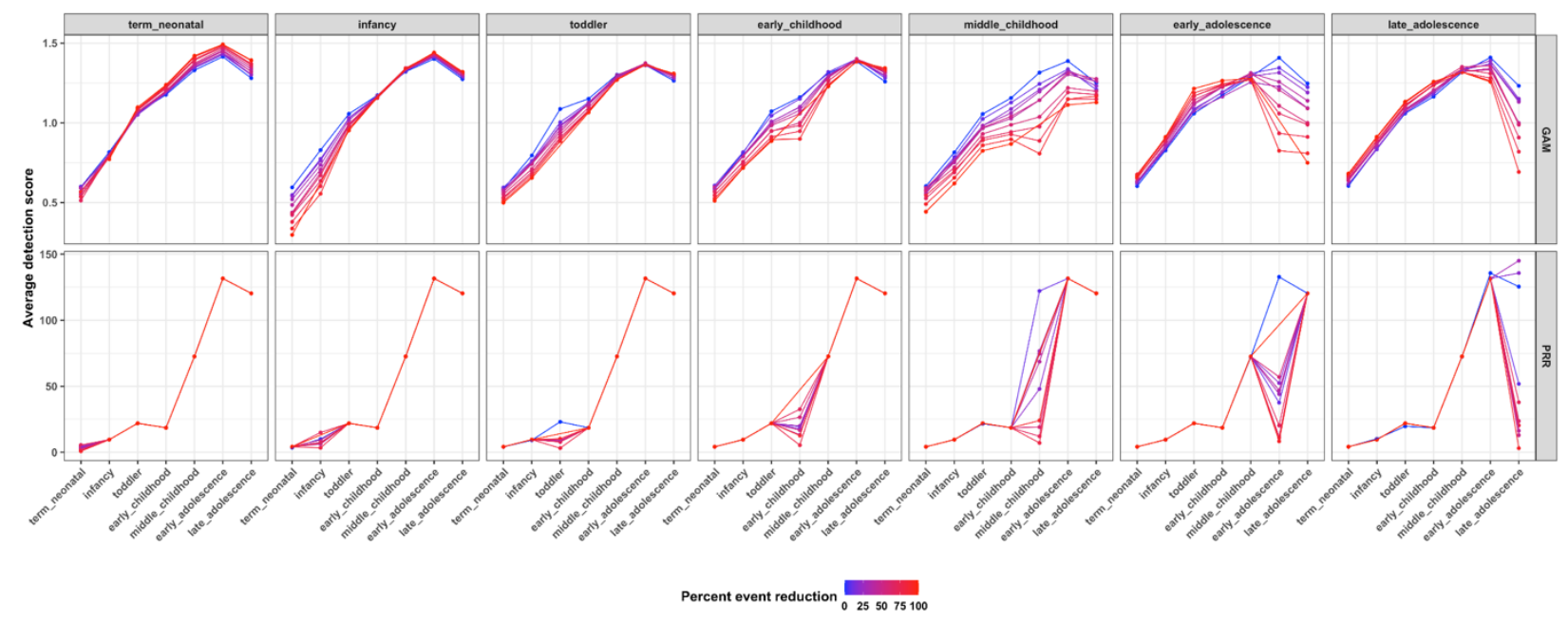

Fig. S5 GAM and PRR detection scores across childhood as adverse events become rare. The average ADE risk scores are shown at each child development stage as event reporting is reduced by $10 \%$ at each child development stage. 
medRxiv preprint doi: https://doi.org/10.1101/2021.03.10.21253302; this version posted March 12, 2021. The copyright holder for this preprint (which was not certified by peer review) is the author/funder, who has granted medRxiv a license to display the preprint in perpetuity.

It is made available under a CC-BY 4.0 International license.

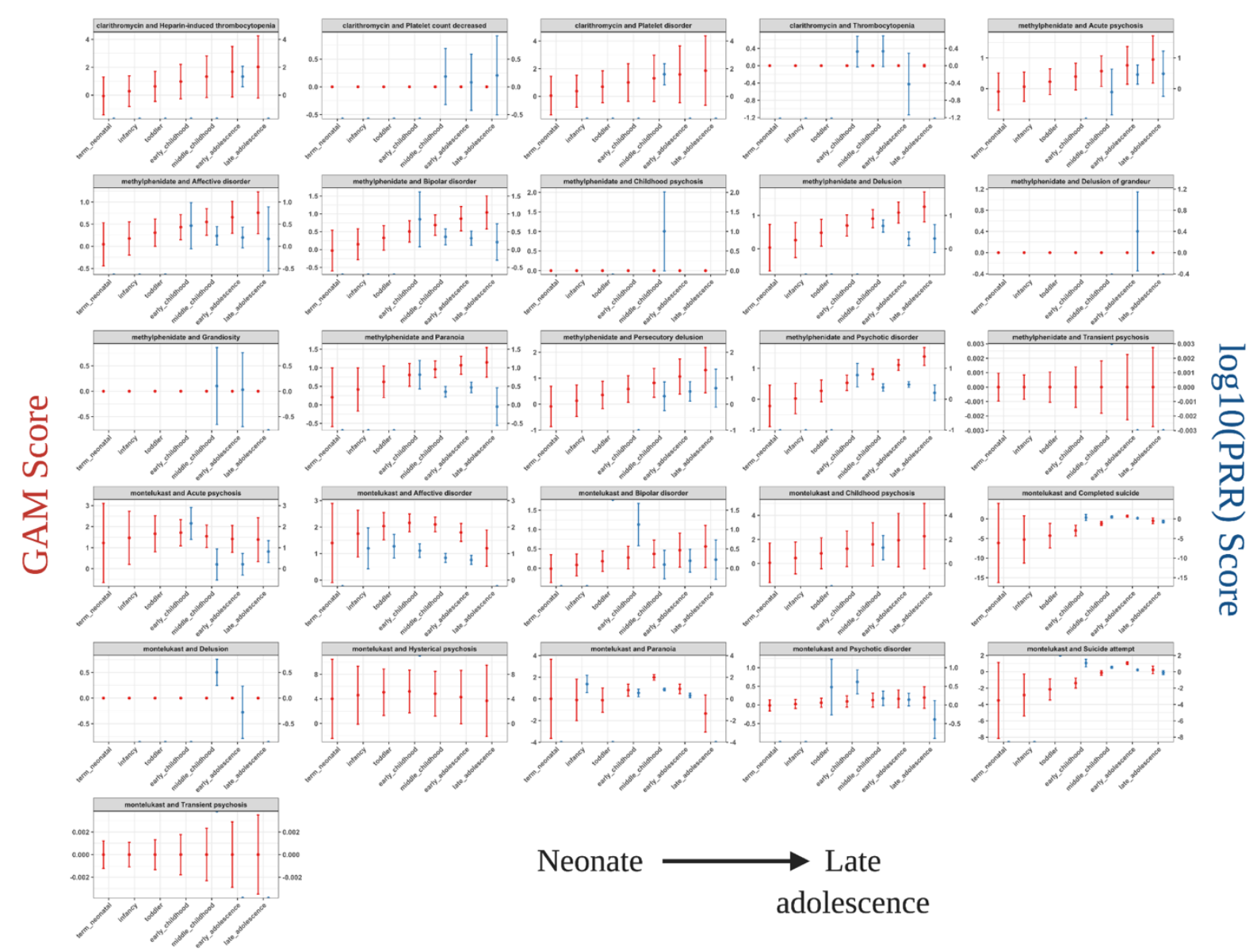

Fig. S6 GAM and PRR score comparison for real-world pediatric drug-events. Application of each ADE detection method on drug-event pairs from the clinically-validated GRiP pediatric reference set. The population score and $90 \%$ confidence interval are shown for each detection method. Only drug-event pairs with epidemiological or mechanistic evidence in children are shown. 
medRxiv preprint doi: https://doi.org/10.1101/2021.03.10.21253302; this version posted March 12, 2021. The copyright holder for this preprint (which was not certified by peer review) is the author/funder, who has granted medRxiv a license to display the preprint in perpetuity.

It is made available under a CC-BY 4.0 International license.

A)

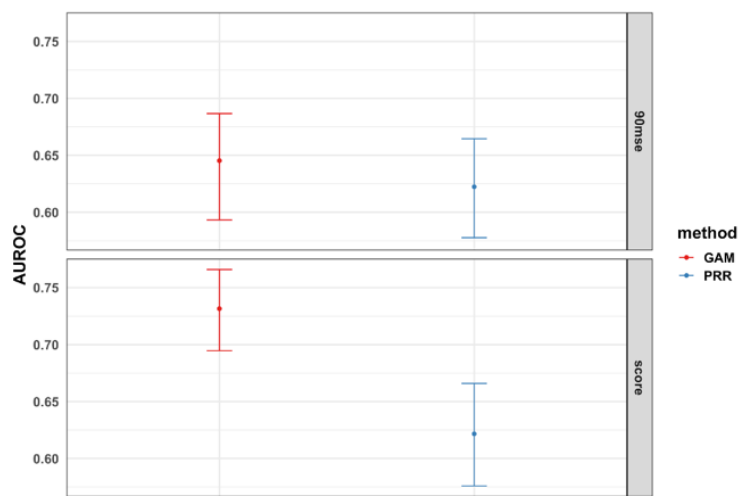

B)

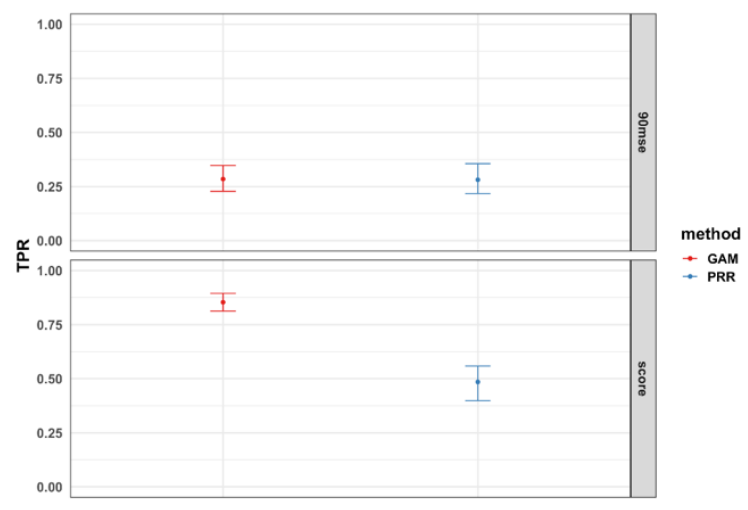

Fig. S7 GAM and PRR drug event real-world drug-event detection performance. A) The area under the receiver operating characteristic curve (AUROC) for detecting risk in real-world pediatric drug-event pairs. B) The true positive rate (TPR) for detecting risk in real-world pediatric drug-event pairs. Intervals represent the $95 \%$ confidence interval for the performance metric.

A)

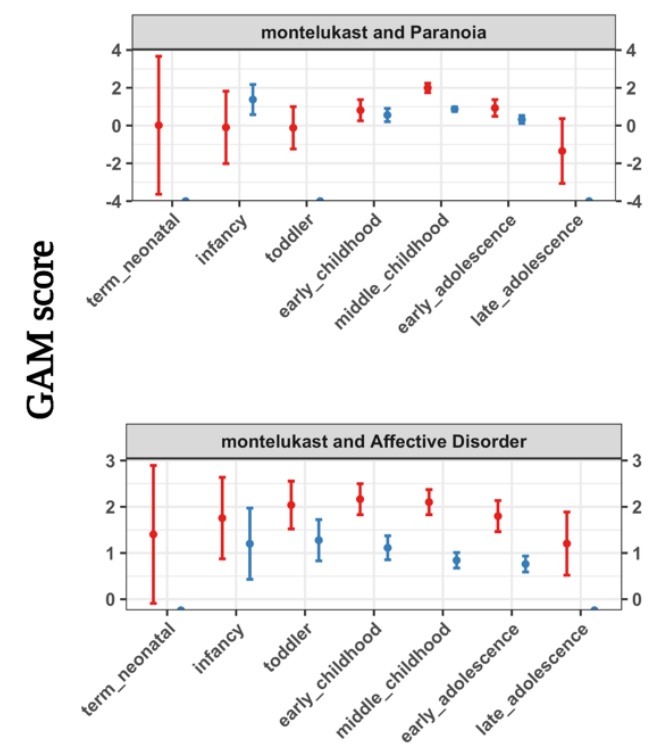

B)

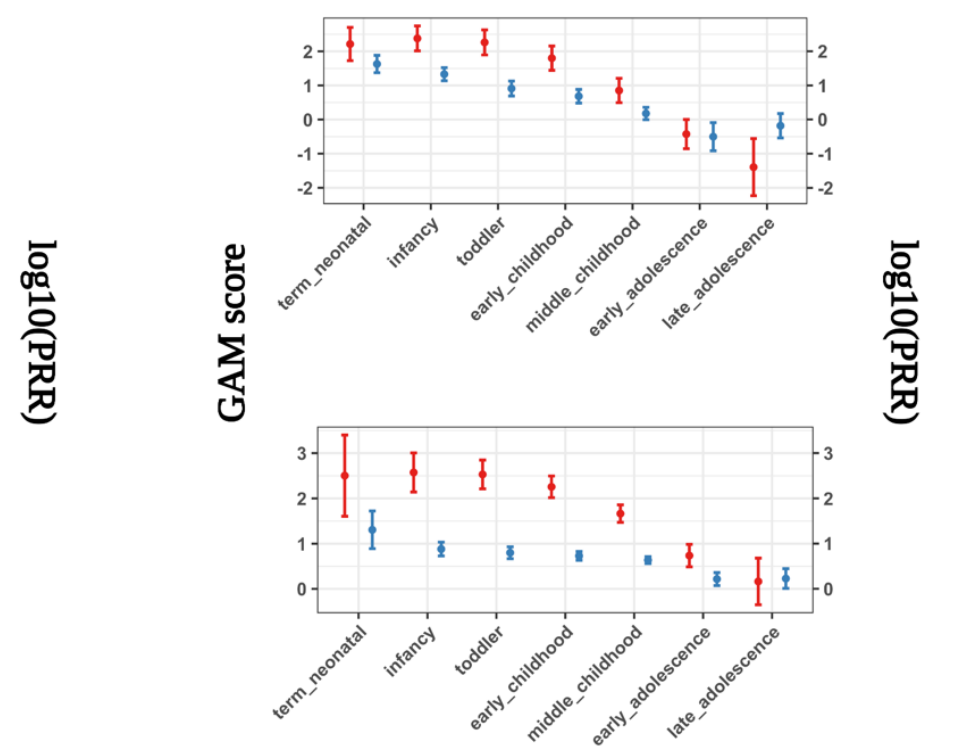

Fig. S8 GAM and PRR detection scores on sample real-world and simulated drug event data. We highlight two drug-event pairs from the A) real-world and B) simulated positive control set where scores across child development stages reflect dynamic ADE risks. 
medRxiv preprint doi: https://doi.org/10.1101/2021.03.10.21253302; this version posted March 12, 2021. The copyright holder for this preprint (which was not certified by peer review) is the author/funder, who has granted medRxiv a license to display the preprint in perpetuity.

It is made available under a CC-BY 4.0 International license .

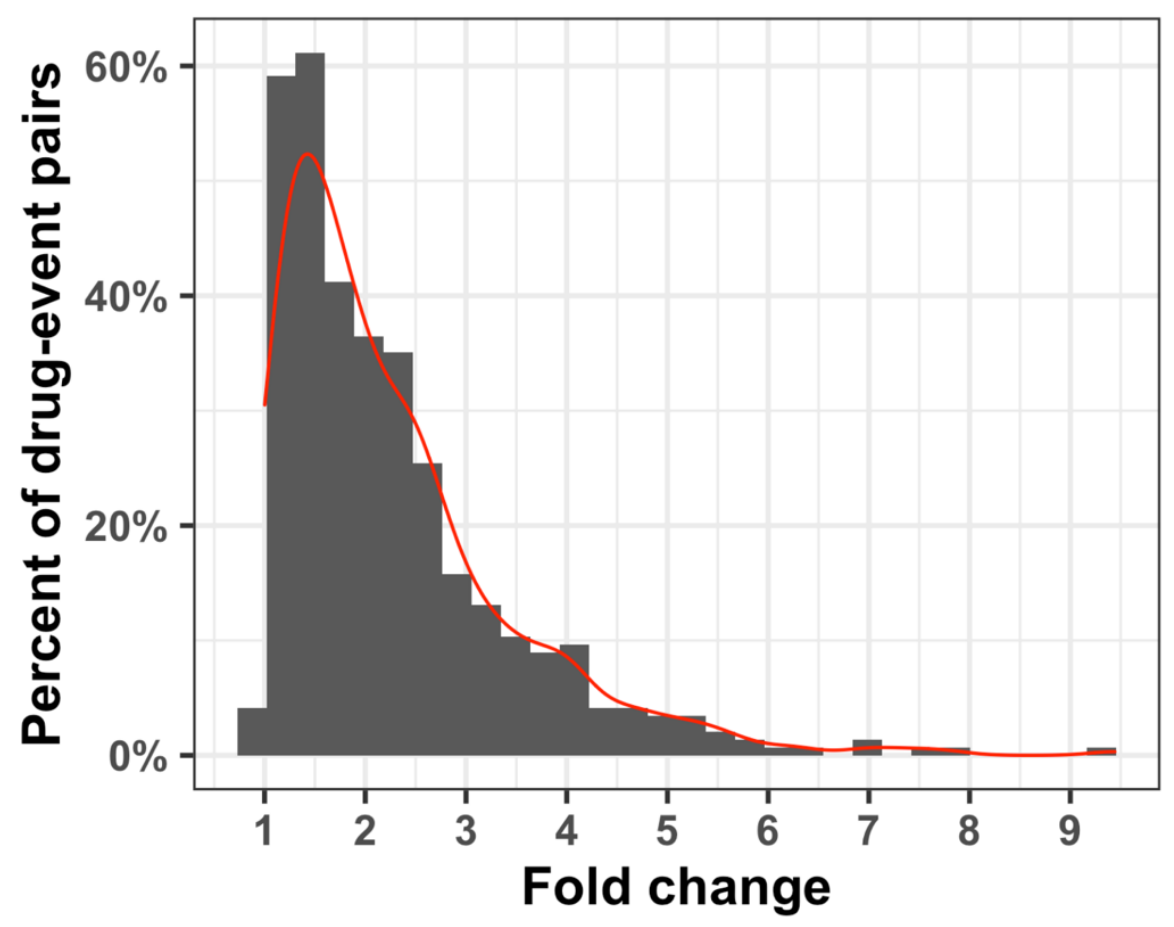

Fig. S9 Distribution of fold-changes for generating drug event dynamics of varying magnitudes. Distribution of fold-changes randomly assigned to drug-event pairs in the positive control set for each dynamics class. 


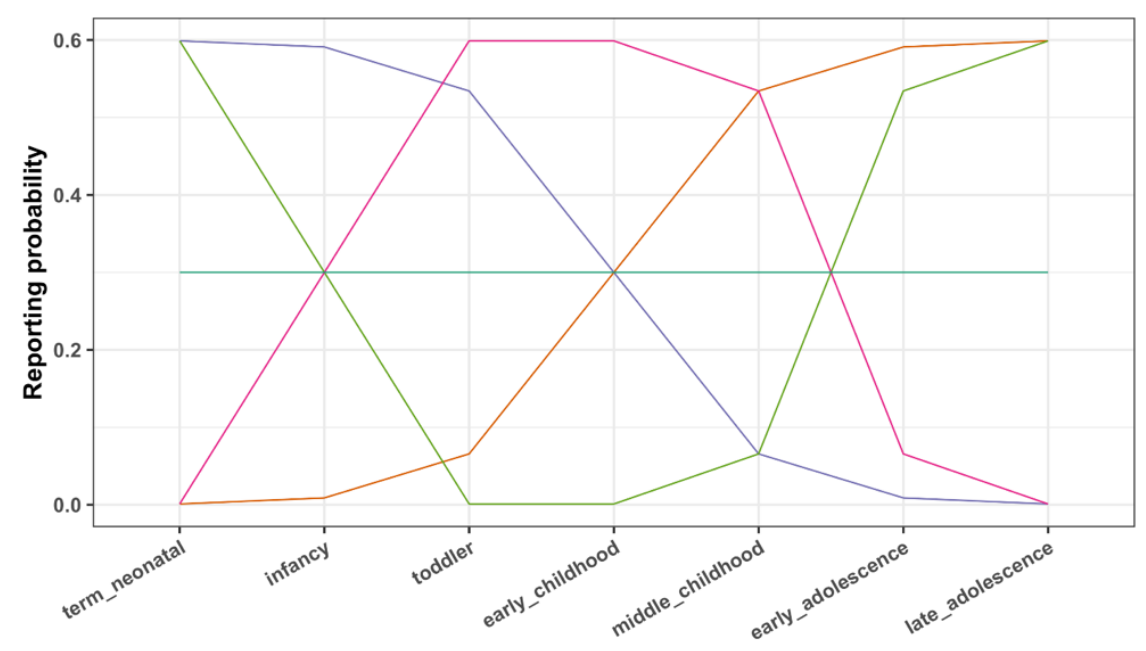

Drug event dynamics class

- decrease - increase - inverse_plateau - plateau - uniform

Fig. S10 Drug event reporting probability rates across child development stages. Each dynamics class represents a drug event reporting probability trend for drug-event pairs in the positive control set. An effect size, here 0.3 , determined the magnitude of the drug event reporting dynamic. The average drug and event reporting across reports equaled the event reporting rate multiplied by a fold change factor resulting in the effect size of dynamic ADE reporting. 
medRxiv preprint doi: https://doi.org/10.1101/2021.03.10.21253302; this version posted March 12, 2021. The copyright holder for this preprint (which was not certified by peer review) is the author/funder, who has granted medRxiv a license to display the preprint in perpetuity.

It is made available under a CC-BY 4.0 International license .

Table S1 High and low drug, event reporting at child development stages for across each dynamics class.

\begin{tabular}{|c|c|c|c|c|c|c|c|c|}
\hline \multirow{2}{*}{\multicolumn{2}{|c|}{$\begin{array}{l}\text { Relative reporting rate within } \\
\text { drug-event pairs at child } \\
\text { development stages }\end{array}$}} & \multicolumn{7}{|c|}{ NICHD child development stages } \\
\hline & & \multirow{2}{*}{\begin{tabular}{|c|} 
Term neonatal \\
High
\end{tabular}} & \multirow{2}{*}{$\begin{array}{l}\text { Infancy } \\
\text { High }\end{array}$} & \multirow{2}{*}{$\begin{array}{c}\text { Toddler } \\
\text { NA }\end{array}$} & \multirow{2}{*}{$\begin{array}{c}\begin{array}{c}\text { Early } \\
\text { childhood }\end{array} \\
\text { NA }\end{array}$} & \multirow{2}{*}{$\begin{array}{c}\begin{array}{c}\text { Middle } \\
\text { childhood }\end{array} \\
\text { NA }\end{array}$} & \multirow{2}{*}{$\begin{array}{c}\begin{array}{c}\text { Early } \\
\text { adolescence }\end{array} \\
\text { Low }\end{array}$} & \multirow{2}{*}{$\begin{array}{c}\begin{array}{c}\text { Late } \\
\text { adolescence }\end{array} \\
\text { Low } \\
\end{array}$} \\
\hline Drug event & Decrease & & & & & & & \\
\hline & Increase & Low & Low & $\mathrm{NA}$ & $\mathrm{NA}$ & NA & High & High \\
\hline & $\begin{array}{l}\text { Inverse } \\
\text { Plateau }\end{array}$ & High & NA & Low & Low & Low & $\mathrm{NA}$ & High \\
\hline & Plateau & Low & $\mathrm{NA}$ & High & High & High & $\mathrm{NA}$ & Low \\
\hline & Uniform & $\mathrm{NA}$ & $\mathrm{NA}$ & NA & $\mathrm{NA}$ & $\mathrm{NA}$ & $\mathrm{NA}$ & NA \\
\hline
\end{tabular}

Table S2 The number of drug-event pairs after the dynamics power analysis. Methods and scores had differences in drug reporting and effect size thresholds to identify drug, event pairs with atleast $80 \%$ power to differentiate scores between high and low reporting development stages.

\begin{tabular}{|c|c|c|c|c|c|}
\hline \multirow{2}{*}{\multicolumn{2}{|c|}{$\begin{array}{l}\text { Number of drug-event pairs } \\
\text { after the power analysis }\end{array}$}} & \multicolumn{4}{|c|}{ Drug event dynamics class } \\
\hline & & \multirow{2}{*}{$\begin{array}{c}\text { Decrease } \\
282(56.4 \%)\end{array}$} & \multirow{2}{*}{$\begin{array}{c}\text { Increase } \\
283(56.6 \%)\end{array}$} & \multirow{2}{*}{$\begin{array}{c}\begin{array}{c}\text { Inverse } \\
\text { Plateau }\end{array} \\
282(56.4 \%)\end{array}$} & \multirow{2}{*}{$\begin{array}{c}\text { Plateau } \\
282(56.4 \%)\end{array}$} \\
\hline \multirow{4}{*}{ Score } & PRR & & & & \\
\hline & PRR_90mse & $109(21.8 \%)$ & $109(21.8 \%)$ & $109(21.8 \%)$ & $109(21.8 \%)$ \\
\hline & GAM & $109(21.8 \%)$ & $109(21.8 \%)$ & $109(21.8 \%)$ & $109(21.8 \%)$ \\
\hline & GAM_90mse & $68(13.6 \%)$ & $68(13.6 \%)$ & $68(13.6 \%)$ & $68(13.6 \%)$ \\
\hline
\end{tabular}

